\title{
Students' Perceptions and Attitudes toward Working in Tourism Industry in Egypt
}

\author{
Maii Baher Omar \\ Faculty of Tourism and Hotel Management \\ Helwan University
}

\begin{abstract}
This research examines the perceptions and attitudes of undergraduate tourism and hotel students toward aspects of working in tourism industry in Egypt. Four hundred and eighty students in faculty of Tourism and Hotel Management Helwan University- completed a questionnaire of three closed questions, multi-dimensional, and multi-item attitude scale. The results showed a general unfavorable evaluation towards working in tourism industry. It has been argued that the lack of skills in tourism industry in Egypt will grow afterward if problems are not addressed. Overall, the final findings cover aspects of commitment to the industry, so gave negative attitude to working in tourism industry. This highlights the need for tutors adopting tactics and strategies aiming to ensure potential employee after graduation. Moreover, these findings may be given to other faculties of tourism and hotels to make use of. A positive aim of these findings is its role as a useful source of information regarding the perceptions and attitudes of the study sample. As a conclusion, this study offers recommendations to tourism industry professionals and tutors relating to students' expectations of their future work environment. Furthermore, the researcher identifies some limitations of this study and areas for further research.
\end{abstract}

Key words: Perceptions, Attitudes, Tourism students, Egypt

\section{Introduction}

Tourism and hospitality industry is the world's largest and fastest-growing industry (Baum, 2006) with high intensive labor (Cronin, 1990; Hjalager, 2003; Kusluvan and Kusluvan, 2000; Lakin, 2005). Due to orientated nature, some academics suggest the need for educated, skilled and committed staff to maintain high service standards (Cronin, 1990; Kusluvan and Kusluvan, 2000). As most of the interactions between employees and clients are face-to-face, with the service purchased and consumed at the same time; the standard of service provided is of great concern. Employee attitude, performance and behavior are the keys that determinants service quality, which affects customers' satisfaction and loyalty (Heskett et al., 1994; Kandampully, 2007). This satisfaction achieved with employees positive attitude toward their jobs (Rosentbluth, 1991; Zeithaml and Bitner, 1996). As current students are the future employees to enter tourism and hospitality field; it can be anticipated that perception changes may emerge as a result of increased graduators, so may be differ from current employee who ,somewhat, do not have formal tertiary qualifications. There are several experience providers in tourism and hospitality field; so industry leaders does not value a tertiary qualification (specifically a degree), refuse to employ graduates, and opting for employing people with experience instead (Ayres, 2006; Costley, 2011; Dale and Robinson, 2001; Harkison et al., 2011; Jameson and Holden, 2000; Liburd and Hjalager, 2010).

Here, questions rise about graduates who come into tourism industry field, their perceptions, and how these perceptions are formed. Earlier researches has been done on the attitudes of tourism and hotel management high educated students toward working in tourism and hospitality industry (Kusluvan and Kusluvan, 2000; Chellen and Nunkoo, 2010; Jenkins, 2001; Roney and Öztin, 2007); this focus on university students studied in an Egyptian context. This study aims to enhance the current understanding of student perceptions and attitudes of a career in tourism and hospitality industry -within Egypt and elsewhere- as the future employees and managers. It seeks to understand the causes and factors that are attracting or repelling students from joining the industry.

\section{Literature Review}

Tourism and hospitality industry worldwide has been confronted with the problem of attracting and retaining high qualified employees, so led to lack of skilled staff the ever-growing number of tourism and hospitality businesses (Deery and Shaw, 1999; Dermady and Holloway, 1998; Ferris et al., 2002; Freeland, 2000; Heraty and Morley, 1998; Hinkin and Tracey, 2000; Powell, 1999). It is claimed that many characteristics commonly found in tourism and hospitality industry may influence the skills deficiency that currently facing the industry. These characteristics include a young transient workforce, low levels formal qualifications, low pays, part-time workers, high ratio of low skilled jobs, many hours spent outside work hours, large number of migrant and high skilled staff turnover (Aksu and Koksal, 2005; Baum, 2006; Brien, 2004; Deery and Shaw, 1999; Freeland, 2000; Riley et al., 2002; Tourism Division, 2002). These characteristics are added to the problems associated with recruitment and retention of qualified staff. Tourism needs professionals adequately trained to rise to present and future challenges facing the sector. Since the continued prosperity of tourism depends -to a large extent- on well educated, motivated, and committed people who are satisfied with their jobs; it is important to provide tourism students with a positive attitude towards work in their field. The industry image 
is critical to its success and competitiveness in the future, especially while competing with other industries (Baum, 2006). Hence, to achieve competitive advantage through destinations; qualified graduates of tourism and hospitality faculties and higher institutes should have a positive attitude toward working in the field. (Pfeffer, 2005). It is necessary to understand the perceptions and attitudes of students in tourism and hospitality faculties to discover whether they intended to work in field after graduation or not. Insights can be gained into the factors that may produce positive or negative evaluation of the industry. An employer can point to remedial actions for students to have more positive attitude. In addition, educators can learn about the problems, successes, and the chief skills needed to ensure graduates entry in field with the most appropriate skills.

\section{Students' perceptions and attitudes towards tourism industry}

Studies in perceptions and attitudes of undergraduate students in tourism and hospitality reported that students perceive the industry as having poor salaries, low stability, long working hours and bad working conditions. (Aksu and Köksal, 2005; Barron and Maxwell, 1993; Chellen and Nunkoo, 2010; Kim et al., 2010; Kusluvan and Kusluvan, 2000; Richardson, 2008, 2009a; Richardson, 2010a, 2010b; Roney and Öztin, 2007) Students' attitudes determine their commitment to the industry apart from available jobs categories (Richandrson, 2008), their commitments are also associated with factors such as gender (Chuang and Jenkins, 2010), his or her previous related work experience (Domonte and Vaden, 1987), and influences from family members and/or friends in the field. (Airey and Frontistis, 1997). Birdir (2002) surveyed those junior and senior tourism students at the University of Mersin in Turkey to find out why some students were not eager to work in the field after graduation. The main reason stated was the lack of excellence education to enable them success in the field. Irregular working hours was the second major reason. Another study in Netherlands and the UK found that a high percentage-over 70\%- of students in their first year of studying hospitality aspire to work in the field, but as students progressed into their grades; this aspiration decreases to as low as 13\% (Jenkins, 2001).

Richardson (2010a) studied the perceptions of tourism industry and compared the results of domestic with international students in Australia. In comparison to international students, domestic students were more negative towards working in the field. (Richardson, 2010a) Domestic students' fear about a career in the field was that factors they deemed important in a career were missing (Richardson, 2010a). Students require job security, promotional prospects, increased earnings, appropriate initial salary, and a reasonable workload; none of which domestic students believed tourism industry could provide. (Richardson, 2010a). A New Zealand study focused on the attitudes and expectations of tourism graduates from both a pre and post entry point of view (Dewar, et al., 2002). This study noted that an element of glamour the industry initially portrayed to potential students later turns to a negative perception of the industry due to its seasonality and high turnover characteristics (Dewar, et al., 2002). This highlights the disconnection between graduate expectations and the reality of the field (Dewar, et al., 2002). Some research completed on students' perceptions of tourism and hospitality industry reveals that some perceptions are not as bad as first assumed, and that in some countries (Mauritius, Australia and Turkey) students are interested in entering the field (Petrova and Mason, 2004). In Mauritius, Chellen and Nunkoo (2010) found that over 80\% of respondents were pleased to have chosen to study tourism and that they would like to work in the field, with $61 \%$ of respondents not planning to work in any other industry. Also a study on tourism undergraduate perceptions in Turkey found that approximately $65 \%$ wanted to work in the field once they had graduated and surprisingly a higher percentage (76\%) of respondents had work experience in the industry (Roney and Öztin, 2007).

Australian school-leavers were also interested in entering the management aspect (58\%), particularly whom family or friends already are employed in the industry (Ross, 1992b). Analyzing students' commitment to the industry; it was revealed in the Mauritius study that student's commitment to tourism and hospitality industry was generally positive (Chellen and Nunkoo, 2010). Students perceived the industry as respected, with an opportunity to learn new things, a good investment in their career development, having promotion opportunities and that the positives of employment in the field outweigh the negatives (Chellen and Nunkoo, 2010). However, not surprisingly that negative perceptions included low payment, long working hours, bad effects on family, employees in the field not being valued, qualifications not necessary and insufficient fringe benefits (Chellen and Nunkoo, 2010). These findings were found in Mauritius, where they could be generalized to a wider context, as other studies conclude similar findings of both negatives and positives (Aksu and Köksal, 2005; Barron and Maxwell, 1993; Kim, et al., 2010; Kusluvan and Kusluvan, 2000; Richardson, 2008, 2009a).

Finally, questions also rose about whether the advantages of tourism industry outweigh the disadvantages. Interestingly, Roney and Öztin (2007) found exactly this, with almost half of their respondents believing that the "advantages of working in tourism field outweigh disadvantages". The image of tourism and hospitality industry being of low payment was not supported, but like other literature as students progress into their study or undertake work experience, their perception became more negative (Roney and Öztin, 2007). However, Richardson's (2009b) results are in contrast to this as $44 \%$ of his respondents thought that the disadvantages outweighed the advantages. There is evidence that not all students are aware of the low payment and long working hours (Petrova and Mason, 2004). This may attract employees into the field, however, once working; they will be exposed to these negative features, which potentially may lead them to leave work. In essence however, it should be expected that negative aspects of anything is 
balanced by positives (Szivas and Riley, 2002). This suggests that it should be expected that the perception of the industry is likely to have some negatives, at the same time, some positives are attributed. Negative and positive perceptions should balances each other;therefore, the industry is not famed in a negative way. The conclusion that can be drawn from this research regarding tertiary students' perceptions can be summed up by Roney and Öztin (2007, p. 9) who suggests that "the general notion of tourism employment appears to be neither positive nor negative". Likewise, Baum (2006) draws a similar conclusion stating that the case cannot be proved anyway. Despite being a mix of positive and negative perceptions; it can also be argued that perceptions are representative of the context from which they are researched further stressing the importance of studying perceptions from a variety of contexts'. The image of the industry is critical to its success and competitiveness in the future, especially while competing with other human resources industries (Baum, 2006). It is necessary to distinguish where these perceptions are formed, to develop ways to overcome negatives.

\section{Methodology}

Faculty of Tourism and Hotel Management of Helwan University was chosen as a target institution for this study out of the seven faculties of tourism and hotels of public universities all over Egypt. This because of being pioneer in tourism and hospitality education in Egypt (Eraqi et al., 2011) in terms of its capacity (1600 undergraduate students), its history (38 years of existence) and its reputation (as the first faculty of tourism and hotels in the Middle East).

A well-structured questionnaire was designed and distributed to the under graduated students, in the fourth grade, who have at least two months summer training experience, and they are more familiar with working environment and conditions of tourism field. This sample was chosen because current students are the future employees to enter tourism and hospitality work field. As a result, future employment status can be drawn.(Chellen and Nunkoo, 2010)

In order to measure perceptions and attitudes of tourism students towards working in the field; a multidimensional and multi item attitude scale was developed. The dimensions are (1) nature of work, (2) social status, (3) Pay/ benefits, (4) Promotion, (5) commitment to the industry. The items in the attitude scale were Likert-type with five categories $(4=$ strongly agree, $3=$ agree, $2=$ disagree, $1=$ strongly disagree and $0=$ have no opinion $)$.Eighteen items were in a negative format, and these were coded in reverse order. The "has no opinion" option was added to prevent forced choices and was not evaluated during the statistical analyses.

To ensure a high response rate and accurate sampling without bias, the questionnaires were self administrated and hand delivered to students. A total of 800 questionnaires were copied taking into account the number of all fourth year students were asked to complete the attitude scale and overall 480 usable questionnaires were returned with a response rate of $60 \%$. Finally, although the initial response rate, some of the returned questionnaires were unusable; because they had too many missing answers or they were half completed. An experimental study was applied - on 40 students enrolled in 4th grade- to check the relevance and clarity of the questions. No changes were required. Data were collected in classes -at the end of the academic year- in April 2013.

\section{Results and Discussions}

\section{Profile of the survey sample}

Questions of this section were collected at the end of the questionnaire because they are simple questions to answer. It was possible that participants may lose interest in completing the questionnaire. In Table 1, almost two thirds (65\%) of the respondents were femalthighs same table shows that (65\%) of the respondents answered negatively to the question of whether they have friends /relatives who work in tourism field. $37.5 \%$ of the sample replied that they may prefer studying tourism if they have been informed about employment conditions in the tourism field before enrolling in college. This means that more than half of tourism students have chosen tourism studies by chance, without realistic knowledge of career opportunities or working conditions. This may be indication of poor guidance before joining the faculty, and improper student selection procedure. 
Table (1): Respondents' profile

Perceptions and attitudes of tourism students toward working in the field

\begin{tabular}{|l|c|c|}
\hline \multicolumn{1}{|c|}{ Profile } & Frequency & Percent \% \\
\hline Gender of the sample & 168 & 35 \\
\hline Male & 312 & 65 \\
\hline Female & & \\
\hline Friends/Relatives who work in the tourism industry & 144 & 30 \\
\hline There are & 312 & 65 \\
\hline There are not & & \\
\hline $\begin{array}{l}\text { Would you still prefer studying tourism if informed about employment } \\
\text { conditions in the tourism industry? }\end{array}$ & \\
\hline Yes & 180 & 37.5 \\
\hline No & 270 & 56.2 \\
\hline Undecided & 30 & 6.3 \\
\hline
\end{tabular}

For simplicity, perceptions and attitudes of undergraduate tourism students towards working in the tourism/ hospitality industry are summarized in group percentages as "strongly agree and agree" and "strongly disagree and disagree" and from this perspective median estimates are calculated. The findings in this study show a close similarity with the study of Kusluvan (2000) and Aksu and Koksal (2005) the answers for the three statements were all positive with high percentage.

The majority of undergraduate tourism students found working in the field is interesting and not boring $(77.4 \%)$, and they found it very nice to contact foreigners and foreign cultures by working in tourism $(82.6 \%)$. Similarly, tourism jobs were seen as providing the opportunity for learning new things everyday (93.5 \%) and over two thirds of students indicated that people working in tourism feel independent and free $(78.7 \%)$. On the other hand, the majority of students indicated that working in tourism field is stressful $(66.7 \%)$, working hours are too long and irregular $(82.6 \%)$, family life is badly affected due to work nature ( $72 . \%)$, and due to its seasonality it is very difficult to find a stable job(82.4\%) as shown in table 2. Job security was another problem; according to Maslow's 'hierarchy of needs' theory, safety and security (together with physiological needs) are the primary needs that must became active sources of motivation. However, employment in tourism field is notoriously insecure because of seasonality, fluctuations in demand, and the high number of part-time and temporary jobs. Therefore, it was not surprising that 76.7 $\%$ of the respondents agreed that it is hard to find job security in tourism, while $77.0 \%$ of them believed that working in tourism field do not provide a secure future and $71.7 \%$ of them disagreed with the statement saying "people with an educational background work in tourism industry". These are negative evaluations of tourism jobs indicating a negative attitude. The previous eleven statements are termed as "nature of work".

There was a very negative attitude towards social status in community dimension of working in tourism. About $78.7 \%$ of the respondents perceived that working in tourism was not a respected (prestigious) vocation, will degrade their moral values $(74.5 \%)$ and it was not seen as important and beneficial service to Egyptian society. Again the majority of students $(83.3 \%)$ believes that "tourism studies graduates will become waiters/waitress" in the Egyptian society. More than half of the students perceived that working in tourism contradict with their religious values (54.3\%), and their parents would not agree to marry their daughters someone working in tourism field (55.5\%).The statements 18-20 relating to pay/benefits in the tourism industry were answered negatively by most of the respondents. Approximately $65.4 \%$ of students regarded salaries as being insufficient to lead to a satisfactory life. Again the majority of students $(72.3 \%)$ indicated that the payment in most tourism careers was low when compared with long and irregular working hours, and working in loads were taken into consideration. Moreover, according to $70.2 \%$ of the sample; the level of fringe benefits like bonuses, leisure time, meals, holidays, ... etc. were insufficient.

An examination of median responses in table 2 -median is two for almost all items on a scale where 3-4 indicate positive attitudes and 1-2 indicate negative attitudes- shows that promotion opportunities were not favorably evaluated in tourism industry. Over two-thirds of respondents believe that promotion opportunities are not satisfactory $(73.9 \%)$, promotions are not handled fairly $(75.2 \%)$ and promotions are unsystematic $(74.5 \%)$. The opportunity of getting promoted to managerial positions is limited $(67.3 \%)$. It is very difficult to get promoted without an uncle in the court $(88.9 \%)$, number of years worked in the field is taken in consideration in promotion decisions were evaluated favorably $(83.3 \%)$. Overall, respondents regarded managers in a negative light -the median is 2 for all items on a scale where 3-4 indicate positive attitudes and 1-2 indicate negative attitude-; managers do not put great effort towards the job satisfaction of employees $(55.8 \%)$. Most managers did not studied tourism science, so they became jealous of undergraduastudy rom tourism faculties (60.9\%). In addition, they do not behave fairly with several employees (55.8\%). 
Table (2): Students' Perceptions and Attitudes

\begin{tabular}{|c|c|c|c|}
\hline How much do you agree or disagree with each statement? & $\begin{array}{l}\text { SA } \\
\text { / A }\end{array}$ & $\begin{array}{l}\mathrm{SD} \\
/ \mathrm{D}\end{array}$ & MD \\
\hline \multicolumn{4}{|l|}{ Nature of Work } \\
\hline Jobs in tourism industry are interesting and not boring & 77.4 & 22.6 & 4.0 \\
\hline To contact foreigners and foreigner culture in tourism is a pleasant experience & 82.6 & 17.4 & 3.0 \\
\hline Working in tourism provides opportunity for learning new things everyday & 93.5 & 6.5 & 3.0 \\
\hline Jobs in tourism are stressful (R) & 66.7 & 33.4 & 2.0 \\
\hline Working hours are too long and irregular for a regular life (R) & 82.6 & 17.4 & 1.0 \\
\hline Family life is negatively affected due to the nature of work (R) & 72.3 & 27.7 & 1.0 \\
\hline It is hard to find a stable job due to seasonality $(\mathrm{R})$ & 82.4 & 17.6 & 2.0 \\
\hline It is hard to find Job security in tourism (R) & 76.7 & 23.3 & 2.0 \\
\hline Working in tourism does not provide a secure future $(\mathrm{R})$ & 77.0 & 23.0 & 2.0 \\
\hline People working in tourism jobs feel independent and free & 78.7 & 21.3 & 3.0 \\
\hline Generally, People with an educational background work in tourism industry & 28.3 & 71.7 & 3.0 \\
\hline \multicolumn{4}{|l|}{ Social status in community } \\
\hline Working in tourism was not a respected vocation in the Egyptian society $(\mathrm{R})$ & 78.7 & 21.3 & 2.0 \\
\hline $\begin{array}{l}\text { It is wide spread belief in the Egyptian society that those who study in tourism will be } \\
\text { waiters/waitress (R) }\end{array}$ & 83.3 & 16.7 & 3.0 \\
\hline Working in tourism contradicts with my religious values $(\mathrm{R})$ & 54.3 & 45.7 & 3.0 \\
\hline Working in tourism will degrade my moral values $(\mathrm{R})$ & 74.5 & 25.5 & 3.0 \\
\hline $\begin{array}{l}\text { Working in tourism is regarded as an important and beneficial service in the Egyptian } \\
\text { society }\end{array}$ & 27.7 & 72.3 & 2.0 \\
\hline Parents would not want their daughters to marry someone working in tourism industry (R) & 55.5 & 44.5 & 1.0 \\
\hline \multicolumn{4}{|l|}{ Pay/benefits } \\
\hline Salaries for most jobs in tourism are insufficient to lead a satisfactory life & 65.4 & 32.6 & 3.0 \\
\hline $\begin{array}{l}\text { The pay was low in the tourism industry considering long working hours and working in } \\
\text { load (R) }\end{array}$ & 72.3 & 28.7 & 2.0 \\
\hline $\begin{array}{l}\text { The level of fringe benefits (bonus/meals, holidays ,etc)are insufficient in the tourism } \\
\text { industry }\end{array}$ & 70.2 & 29.8 & 3.0 \\
\hline \multicolumn{4}{|l|}{ Promotion opportunities } \\
\hline Promotion opportunities are satisfactory in the tourism industry & 26.1 & 73.9 & 2.0 \\
\hline Promotion are handled fairly $(\mathrm{R})$ & 24.8 & 75.2 & 2.0 \\
\hline The opportunity of getting promoted to managerial position is limited (R) & 67.3 & 32.7 & 2.0 \\
\hline Promotions are unsystematic in tourism industry $(\mathrm{R})$ & 74.5 & 25.5 & 2.0 \\
\hline Years worked are taken into consideration in promotion decisions & 83.3 & 16.7 & 3.0 \\
\hline $\begin{array}{l}\text { It is very difficult to get promoted if you do not have "un uncle in court" in tourism } \\
\text { industry (R) }\end{array}$ & 88.9 & 11.1 & 2.0 \\
\hline \multicolumn{4}{|l|}{ Managers } \\
\hline Managers are jealous of undergraduates with a qualification degree in tourism (R) & 60.9 & 39.1 & 2.0 \\
\hline Mangers behave in a fair way to employee in tourism & 44.2 & 55.8 & 2.0 \\
\hline Managers make sure that employee participate in decisions affecting their job & 17.6 & 82.4 & 2.0 \\
\hline Managers do not put great effort into making employees satisfied from their jobs (R) & 55.8 & 44.2 & 2.0 \\
\hline \multicolumn{4}{|l|}{ Commitment to the industry } \\
\hline In general, the disadvantages of working in tourism industry out weight the advantages & 56.5 & 43.5 & 3.0 \\
\hline I am happy to choose tourism as a career path & 23.9 & 76.1 & 2.0 \\
\hline I would not recommend to my friend or my child & 68.8 & 31.2 & 3.0 \\
\hline Intention to work in the tourism industry after graduation & 35.0 & 65.0 & 2.0 \\
\hline $\begin{array}{l}\text { I recommended a job in the tourism industry to my friends and relatives because it is very } \\
\text { nice to be a part of this industry }\end{array}$ & 39.1 & 60.9 & 2.0 \\
\hline It was a big mistake to choose tourism as a career path (R) & 34.1 & 65.9 & 2.0 \\
\hline
\end{tabular}

Note: $N=480$.

Adjusted (corrected) per cent excluding missing observations.

Scale: $4=$ Strongly Agree; $3=$ Agree; $2=$ Disagree $1=$ Strongly Disagree.

(R): These items are reverse coded: $1=$ Strongly Agree; $2=$ Agree; $3=$ Disagree; $4=$ Strongly Disagree

$\mathrm{SA}$ : strongly agree, A: agree, SD: strongly disagree, D: disagree, MD: median. 
In addition, managers do not let employees participate in making decisions affecting their particular job (82.4 $\%)$. As might be inferred from previous evaluations of different attitudes, it is very difficult to conclude that respondents have a strong commitment to working in the tourism field. Over half of students $(56.5 \%)$ indicated that the disadvantages of working in the field outweigh the advantages. Only (39.1\%) of students surveyed reflected a positive attitude towards commitment to the industry. These positive answered statement were as follows; "I recommended a tourism job to my friends and relatives as it is very nice to be a part of the industry" and "It was a big mistake to choose tourism as a career path". Weak commitment of respondents to the tourism industry is also implied by the fact that most of students did not prefer their friend or child $(68.8 \%)$ to study tourism science, work in the field, and weak intention to work in the field after graduation (35\%). Overall, these final findings covering aspects of commitment to the industry give a negative value to working in tourism field.

\section{Conclusion and Recommendations}

This study shows that undergraduate students who are studying tourism and hotel management in Egypt did not preferred different aspects of working in tourism industry. This highlights the need for the industry and educators to adopt tactics and strategies aimed to ensure the potential employee i.e. tourism and hospitality students are not eager to enter the industry after graduation. There is a number of elements; particularly payment and benefits, working hours, job stability and security, promotion and managers behavior, that the industry must focus on to ensure that students receive positive experience and perceptions of the industry. Hence, the results of the study revealed that there was not a strong commitment to tourism industry among undergraduate students surveyed. To increase positive attitudes at the side of tourism students towards working in the field, there are two issues that must be addressed. First, tourism and hotels industry needs to build a positive image to improve the perceptions of its students by getting them accurate information. In this regard, it is suggested that career guidance should be made more efficient prior to beginning their programmes to minimize the gap between expectations and perceptions by giving all potential students an extensive overview of careers available in the field and the working conditions on offer, including pay levels, promotion opportunities and career paths on offer so that their career decisions are based on choice rather than chance. As indicated in this study many students seem to enroll in tourism degrees having inadequate knowledge of the employment conditions in tourism industry.

If students were informed sufficiently about careers and working conditions in tourism industry, they would form more realistic and lower expectations with regard to jobs in the field (Kusluvan and Kusluvan, 2000). This will reduce the graduates who develop negative attitudes toward a career in the field, as they will be informed about the real status of working in the field. Potentially, this will reduce the number of skilled and trained employees that may leave or even fail to enter the industry after graduation. Tourism and hotel educators may help overcoming this problem. They also might invite more industry representatives to give shared seminars to students and their parents. New tourism employees who are graduated in tourism and hotel management faculties should participate. They will have similar backgrounds to current students, and their parents could also be encouraged to attend these seminars to express their opinions about the career from both parents' and undergraduate students' perspectives. Finally, Tourism and hotel educators should seek to cooperate with the tourism industry in carrying out applied research that would benefit the whole community in the long term. The second issue that needs to be addressed is improving many aspects of the work conditions within tourism industry. As stated above, there is number of elements that students believe the industry is behind other industries, particularly, in regards to nature of work, pay/ benefits and promotion opportunities dimensions. Where there is no will to improve conditions for employees on the part of the private sector, the public sector law makers can be called to regulate human resource policies and practices in tourism industry which is a trend in many countries. For example, tourism and hospitality firms may be obliged to make up a certain proportion of their work-force of tourism and hotel management graduates. Determination of minimum salaries, maximum weekly or daily working hours or working from home and flexible schedules are other areas where law makers can intervene (Aksu and Koksal, 2005).

Government officials must have essential corrections suitable for the needs of students in Egyptian work law, hold many formal researches to delve further and obtain data why students declined to join the hospitality and tourism industry. If the industry could not change the student's negative perceptions, it will continue to lose the skilled and trained employees. Perhaps with greater push from the government and better incentives provided by both the industry and the government, more local young adults will re-evaluate the industry and choose this industry, so this maximizes the number of university graduates who entering and continuing in the field. In the long term, the general employment conditions in the industry could be improved to enable today's students with formal qualifications to become the effective future managers. The student participants were limited to students in one faculty which is Faculty of Tourism and Hotel management, Helwan University. Further study needs to involve more students from other universities and institutions, to produce more accurate data. This research also can be repeated in different regions or countries so that attitudes of undergraduate tourism students towards careers in the field can be compared. Furthermore, a comparison between students' perceptions and parents', in terms of parental influence on the students career choice, might be another interesting topic for future research. Finally, further research should focuses on the perceptions of educatirs and 


\section{Students' Perceptions and Attitudes toward Working}

managerial employees in tourism industry, which may help them understanding each other. The results will be valuable to educators, students, and the industry as well.

\section{References}

Airey, D. and Frontistis, A. (1997). Attitudes to Careers in Tourism: An Anglo-Greek comparison. Tourism Management, 18(3), 149-158.

Aksu, A.A. and Köksal, C.D. (2005). Perceptions and Attitudes of Tourism Students in Turkey. International Journal of Contemporary Hospitality Management, 12(5), 436-447.

Ayres, H. (2006). Education and Opportunity as Influences on Career Development: Findings from a Preliminary Study in Eastern Australian Tourism. Journal of Hospitality, Leisure, Sport and Tourism Education, 5(1), 16-27.

Barron, P. and Maxwell, G. (1993). Hospitality management students' image of the hospitality industry. International Journal of Contemporary Hospitality Management, 5(5), 5-8.

Baum,T.(2006). Human Resource Management for Tourism, Hospitality and Leisure: An International Perspective. Thomson Learning, London.

Birdir, B. (2002) Turizm ve otel isletmeciliği eğitimi alan lisans: In: Ministry of Tourism (ed.), Proceedings of the conference and workshop on tourism education, 495-504.Ankara: Ministry of Tourism Press.

Brien, A., (2004). Do I want a job in hospitality? Only till I get a real job!. In: Smith,K.A., Schott, C. (Eds.), Proceedings of the New Zealand Tourism and Hospitality Research Conference, Wellington, NZ.

Chellen,H. and Nunkoo,R. (2010). Understanding Students' Commitment to Employment in the Tourism and Hospitality Industry. Paper presented at the International Research Symposium in Service Management, Mauritius.

Chuang, N.-K. and Jenkins, M. (2010). Career decision making and intention: A study of hospitality undergraduate students. Journal of Hospitality and Tourism Research 34(4), 512-530.

Costley, W. (2011). Innovations in Masters Degrees. Paper presented at the The-ICE International Panel of Experts Forum, Taylors University, Malaysia.

Dale, C. and Robinson, N. (2001). The Theming of Tourism Education: A Three-domain approach. International Journal of Contemporary Hospitality Management, 13(1), 30-35.

Dermady,M. and Holloway,R.(1998). Recruitment and retention of managers: developing a management career package. Cornell Hotel and Restaurant Administration Quarterly 39 (6), 20-25.

Deery, M. and Shaw, R., (1999). An investigation of the relationship between employee turnover and organizational culture. Journal of Hospitality \& Tourism Research 23 (4), 387-400.

Dewar, K., Sayers, J and Meyer, D. (2002). Hopes, Dreams, and Reality: An Investigation into the Expectations and Experiences of Tourism Graduates. Journal of Teaching in Travel \& Tourism, 2(1), 1-18.

Domonte, T. and Vaden, A. G. (1987). Career decisions in hospitality management. International Journal of Hospitality Management, 11(1), 51-63.

Eraqi, M, Abou-Alam, W, Belal, M and Fahmi. T (2011). Attitudes of Undergraduate Students toward E-Learning in Tourism: The Case of Egypt, Journal of Teaching in Travel and Tourism, 11:4, 325-348.

Ferris, G.R., Berkson, H.M. and Harris, M.M., (2002). The recruitment interview process persuasion and organization promotion in competitive labour markets. Human Resource Management Review 12, 359-375.

Freeland, B., (2000). Demands of training: Australian tourism and Hospitality. National Centre for Vocational Education Research, Adelaide.

Harkison, T., Poulston, J. and Kim, J. H. (2011). Hospitality graduates and managers: the big divide. International Journal of Contemporary Hospitality Management, 23 (3), 377-392.

Hjalager, A. (2003). Global tourism careers? Opportunities and dilemmas facing higher education in tourism. Journal of Hospitality, Leisure, Sport and Tourism Education, 2(2), 26-37.

Heraty, N. and Morley, M., 1998. In search of good fit: policy and practice in recruitment and selection in Ireland. The Journal of Management Development 17 (9), 662-685.

Heskett, J. L., Jones, T. O., Loveman, G. W., Sasser Jr., W. E. and Schlesinger, L. A. (1994). Putting the service-profit chain to work. Harvard Business Review, 72 (March- April), 164.

Hinkin, T. and Tracey, J. (2000). The cost of turnover. Cornell Hotel and Restaurant Administration Quarterly 43 (1), $14-21$.

Jameson, S. M. and Holden, R. (2000). "Graduateness"-who cares? Graduate identity in small hospitality firms. Education+ Training, 42(4/5), 264-271.

Jenkins, A. K. (2001) Making a career of it? Hospitality students' future perspectives: an Anglo-Dutch study. International Journal of Contemporary Hospitality Management, 13(1), 13-20.

Kandampully, J. (2007). Service management: The new paradigm in hospitality. Upper Saddle River, NJ: Pearson Prentice Hall.

Kim, B., Mc Cleary, K. W. and Kaufman, T. (2010). The New Generation in the Industry: Hospitality/Tourism Students' Career Preferences, Sources of Influence and Career Choice Factors. Journal of Hospitality and Tourism Education, 22(3), 5-11.

Kusluvan, S. and Kusluvan, Z., (2000). Perceptions and attitudes of undergraduate tourism students towards working in the tourism industry in Turkey. Tourism Management 21, 251-269. 
Lakin, A. (2005). Careers and Employment. In D. Airey \& J. Tribe (Eds.). An International Handbook of Tourism Education (pp. 437-450). Oxford: Elsevier

Liburd, J. and Hjalager, A.M. (2010). Changing Approaches towards Open Education, Innovation and Research: In Tourism. Journal of Hospitality and Tourism Management, 17(1), 12-20.

Petrova, P. and Mason, P. (2004). The value of tourism degrees: a Luton-based case study. Education and Training, 46(3), 153-161.

Pfeffer, J., (2005). Producing sustainable competitive advantage through the effective management of people. The Academy of Management Executive 19 (4), 95-108.

Powell, S., (1999). Is recruitment the millennium time bomb for the industry worldwide? International Journal of Catering and Hospitality Management 11 (4), 138-139.

Riley,M. , Ladkin,A. and Szivas, E.,(2002) Tourism Employment : Analysis and Planning. Channel View Publications, Sydney

Richardson,S. (2008).Undergraduate Tourism and Hospitality Students Attitudes toward a Career in the Industry: Journal of Teaching in Travel and Tourism, 8(1), 23-46

Richardson, S. (2009a). Undergraduates' perceptions of tourism and hospitality as a career choice. International Journal of Hospitality Management, 28(3), 382-388.

Richardson, S. (2010a). Tourism and Hospitality Students' Perceptions of a Career in the Industry: A Comparison of Domestic (Australian) Students and International Students Studying in Australia. Journal of Hospitality and Tourism Management, 17(1), 1-11

Richardson, S. (2010b). Understanding Generation Y's Attitudes towards a Career in the Industry. In P. Benckendorff, G. Moscardo \& D. Pendergast (Eds.), Tourism and Generation Y (pp. 131-142). Oxfordshire: CABI Publishing

Roney, S. A. and Öztin, P. (2007). Career perceptions of undergraduate tourism students: a case study in Turkey. Journal of Hospitality, Leisure, Sports and Tourism Education, 6.

Ross, G. F. (1992b). Tourism management as a career path: vocational perceptions of Australian school leavers. Tourism Management, 13, 242-247.

Rosentbluth, H. (1991).Tales from a non conformist company. Harvard Business Review, 69 (July-August), 26-36.

Szivas, E. and Riley, M. (2002). Labour Mobility and tourism in the post 1989 transition in Hungary. In C. M. Hall and A. M. Williams (Eds.), Tourism and Migration: New Relationships between Production and Consumption (pp. 5372). Norwell: Kluwer Academic Publishers

Tourism Division, (2002). Research Report Number 4: Tourism Workforce and Training. Retrieved April 12th, from http://www. Industry.gov.au/ assets/ documents/itrinternet/4.ResearchReport No4 Tourism Workforce and Training 20050202121253.pdf.

Zeithaml, V. A. and Bitner, M. Jo. (1996). Services marketing. New York: McGraw-Hill.

Zhou, J. L. (2001). A current look at hospitality and tourism education in China's colleges and universities. International Journal of Hospitality Management, 10(4), 357-367.

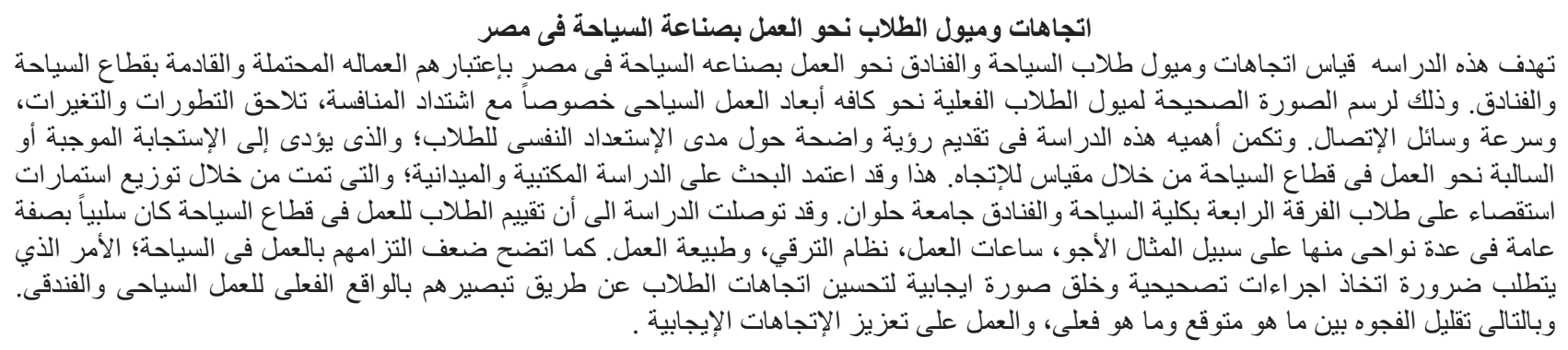




\title{
Obstacles to the Adoption of Self-Service Technology at Cairo International Airport
}

\author{
Ghada Mohamed Khairat \\ Faculty of Tourism and Hotels \\ University of Sadat City
}

\begin{abstract}
Due to the advancement and proliferation of information and communication technologies in today's world, self-service technology (SST) applications have become increasingly prevalent. SST is a technology that enables users to produce a service independent of direct service employee involvement. As more and more airlines have introduced technology-based self-check-in services, it has become increasingly important to understand the factors affecting airline passengers' attitudes and intentions toward this new form of check-in services. Therefore, this study aims at investigating passengers' intention toward using check-in kiosks and exploring the obstacles to applying self-service check-in kiosks at Cairo International Airport. The field study is based on in-depth interviews with 20 Executive directors of Cairo International Airport, Station directors, employees of Egypt Air, and 30 passengers at Cairo International Airport. The results indicate that passengers are not commonly using Self-service check-in kiosks and had rejected the kiosks due to some obstacles. Finally, this study suggests that airlines should persuade passengers to acquire a more positive attitude toward the new check-in kiosks. Airlines also should implement incentive strategies to encourage passengers adopting the self-check-in service.
\end{abstract}

Keywords: Self-service technology; Airline check-in kiosk; Technology readiness.

\section{Introduction}

Rising labor costs have encouraged companies to explore more self-service options that allow customers to perform services by themselves. Moreover, innovations in technology have contributed to the growth of technology-based self-services, allowing companies to use a variety of self-service technologies (SSTs) that increase customer participation. ${ }^{1}$ Self-service technology (SST) is defined as technological interfaces that aid users in generating service without direct involvement from the service company's employee. ${ }^{2}$ SST has become more and more widespread and replaced traditional face-to-face services. ${ }^{3}$ It has changed how existing companies do business and enabled the creation of new types of business ${ }^{4}$ SSTs have dramatically changed the way in which firms interact with customers, ${ }^{5}$ giving the customer the duty to carry out the service with the use of technology either through internet or visual aids. This type of technology is moving the responsibility to the customer ${ }^{6}$ The replacement of human service by a technology usually requires both the development of new knowledge and behavior associated with the service and increased customer responsibility in the production of the service . ${ }^{7}$ Many service providers have begun to use a wide range of technologies in the process of service delivery, allowing customers to enjoy services electronically without direct contact with service employees . ${ }^{8}$

The benefits of SST adoption include labor cost reduction, enhancing efficiency, ${ }^{1,5}$ improving productivity and service quality.$^{9}$ It also increases corporate performance, improves service operations, ${ }^{8}$ improves competitiveness and increases market share, increases customer satisfaction and customer loyalty, and differentiates through a technological reputation .${ }^{10,11}$ From the customers' perspective, SSTs enable them to enjoy the services they require with a more flexible choice of time and space, and through more channels.$^{8}$ Although self-service technology can bring the benefits of convenience, perceived control, and flexibility to customers, in the rush to implement SST, firms often disregard technology failures and the associated risk of losing customers because of technology related difficulties.$^{12}$ However, technological problems such as technology failures, process failures, service design problems, technology design problems, and customer driven failures may inhibit the adoption of self-service technology. The challenge facing self-service technology is about getting customers to use the technology.$^{13}$ So, adopting SST does not necessarily result in a positive outcome, ${ }^{14}$ and does not automatically lead to its usage. Many technological innovations are radical or really new to customers, and cause apprehension in those who lack sufficient experience with the technology.$^{15}$ Customers may avoid it if they are not comfortable with and/or ready to use the technology. Moreover, customers' adoption of technology will vary according to the characteristics of the individuals. When customers face technology, different psychological reactions occur, depending on the individuals' feelings toward the technology-based system ${ }^{8}$ 
The key determinants of SST intention can be generally classified into two broad categories: SST characteristics and individual differences. So far, the main SST characteristics include usefulness, ease of use, enjoyment, risk, and control. In terms of individual differences, they can be further categorized into demographics and psychographics. Primary demographics that have been found to influence SST usage intention are age, gender, education, and income; whereas main customer psychographics include technology anxiety, technology readiness, and need for human interaction.$^{16,3,17}$ Air traffic is growing continuously, but the development of airports is constrained by the funding and space available to expand the terminal. Therefore, airports have to develop the terminal facilities and meet new standards of operational efficiency. Airports have started implementing new technologies at the terminals for convenience of the passengers. The new solutions strive to improve operational efficiency and reduce queues at the airport.$^{18}$ Airport infrastructure is the first and the last point of contact at a destination. The new technology like self-service kiosks are designed as one form of airport infrastructure and act as a time saver for passengers, cost saver for airlines, and space saver for airports. Most major airlines have already invested in installing self-service kiosks to save expense at the check-in, offer a better service to their passengers, and build an image of maintaining a leading position in electronic service ${ }^{\mathbf{1 9 , 2 0}}$ Now airlines and airports are using new procedures to deliver faster and smoother services to airline passengers.$^{21}$ The aim of this study is to investigate passengers' intention toward using SST for airline check-in kiosks, and explore the obstacles to use self-service check-in kiosks at Cairo International Airport.

\section{Literature Review}

Self-service technology (SST) is technology interface that enables customers to produce and use a service independent of direct service employee involvement; ${ }^{22,23,24}$ and it allows customers to interact with self-service software. ${ }^{25}$ Examples of SST in use are ATM, Pay at the pump, Internet banking, Airport self-check-in, Automated hotel check-in/out, Automated car rental, gambling machines, distance learning/training, Internet information search, Internet shopping, Automated driver's license testing, various vending services, food ordering kiosks and various interactive voice response phone systems. $^{26,27}$

\section{Types of SSTs}

There is a classification which has divided SSTs into four dimensions: ${ }^{\mathbf{1 2 , 2 8}}$

1) Telephone \& Interactive Voice Response (IVR) systems which allow consumers to interact with a computer system through speech recognition technology. Companies can provide information over the telephone using text-to-speech technology. Furthermore, many companies utilize this form of SST for customer orders, customer billing inquiries, and customer surveys.

2) Interactive free-standing kiosks which provide users access to information or a service, such as checking an account balance at an ATM or checking in for a flight at an airport kiosk. Many malls and retail outlets offer such services both inside and outside their stores. This helps customers determine availability of a product, as well as locate it in their facility. There are also print coupons kiosks at airports and hotels which allow printed airline tickets and quick checkout. Today's technology makes kiosks more affordable and convenient. Kiosks are often equipped with advanced technology like touch screen displays, card readers, scanners, thermal printing, Power over Ethernet (PoE+) and wireless networks. The availability of broadband Internet access has made deploying consumer-friendly computer kiosks a cost-effective option for many services . ${ }^{\mathbf{2 9 , 3 0}}$

3) Internet based and other direct online connection systems.

4) Video/DVD/CD based technologies: This type of SST is typically used for educational purposes. Corporate entities use this media to train their employees, to familiarize sales representatives with new products, and to introduce new products to customers. Universities have also gotten into the act in the last decade, providing undergraduate, graduate, and continuing education classes by video and CD formats.$^{31}$

Additionally, according to ${ }^{32,22}$, SST is divided into two groups: Internet and non-Internet SSTs. Examples of Internetbased SSTs are online banking, online tax-file number registration, online hotel or airline reservation and transaction. More advanced tools continue to be introduced by firms as a response to the competitive business environment and the availability of more innovative technology. Examples of Non-Internet SSTs are ATMs or vending machines, self-cash registers in grocery stores, information kiosks at malls, automated hotel checkout processes, automated self-check-in machines in the airports, and self-scanning machines in the library are very common. On the other hand, ${ }^{33}$ SST is segmented into three application areas: online (e-commerce), kiosk (k-commerce), and vending (v-commerce). 


\section{Business Goals for SST}

Companies typically seek to fulfill at least one of three primary business goals when they choose to enter the self-service arena ${ }^{12,34,35,36}$

1) Customer service (technology delivered customer service): The intent here is to provide the customer service without tying up the company's human resources. Questions regarding accounts, bill paying, frequently asked questions, and delivery tracking are just a few examples of customer service that are now provided through SSTs.

2) Direct transactions: The technology enables customers to contact with companies to order, buy and exchange resources without any direct interaction with the companies' employees.

3) Educational (Self-Help): which refers to technologies that enable customers to learn, receive information, train themselves, and provide their own services.$^{37}$

\section{Factors Affecting SST Adoption and Use}

The successful implementation of SSTs is dependent on wide customer adoption in order to justify the investment cost. Therefore, the need to understand customer decisions regarding SSTs has drawn scholars' attention into the factors facilitating customer adoption.$^{38}$ It is important to understand the factors that determine both willingness and resistance of the customers on using the SSTs.$^{39}$ many factors influence the adoption or rejection of technology-enabled services. These factors include: innovation attributes and customer characteristics, ${ }^{\mathbf{1 2 , 4 0 , 4 1}}$ see figure $\mathbf{1 .}$

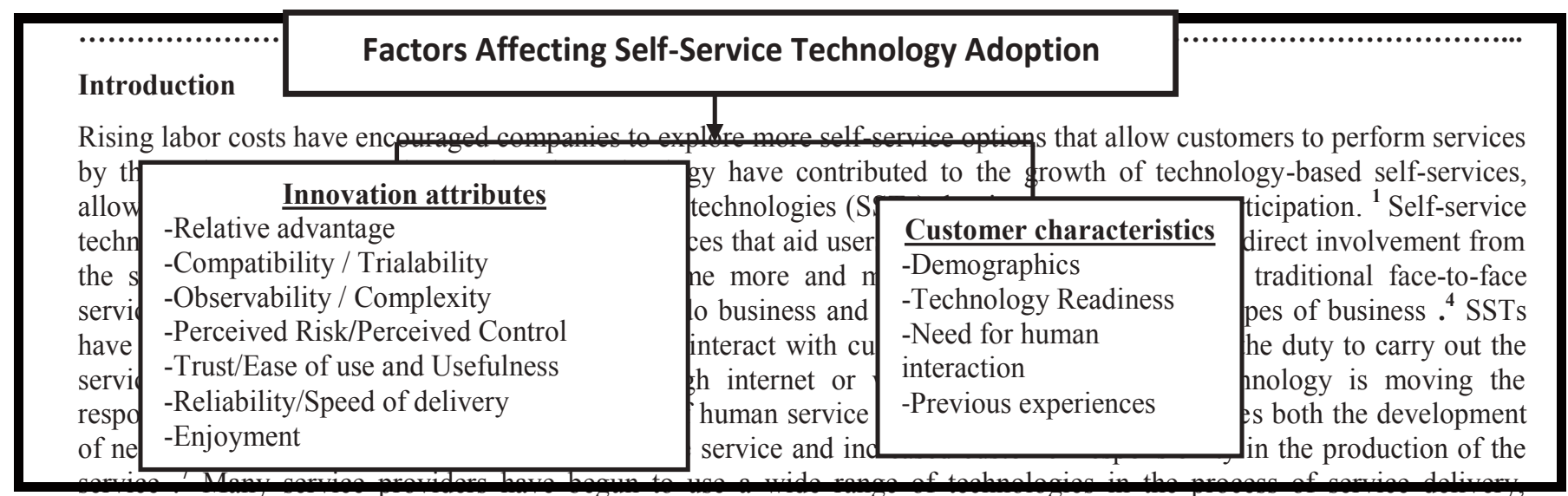

Figure (1): Factors affecting Self-Service technology adoption

\section{Self-Service Technology Characteristics:}

The adoption rate of an innovation is determined by the customers' perceptions of the innovation characteristics. five innovation attributes are considered to be important: relative advantage, compatibility, trialability, observability, and complexity. ${ }^{3}$ In addition, a large number of studies have also investigated other innovation attributes such as, perceived risk. ${ }^{32}$ perceived control, ${ }^{42}$ trust, ${ }^{9}$ perceived ease and perceived usefulness, ${ }^{38}$ reliability, speed of delivery, and enjoyment . ${ }^{41,43,44}$

- Relative advantage is defined as "the degree to which an innovation is perceived as being better than the idea it supersedes", whereby the relevance of the advantage depends on the nature of the innovation, and the extent to which services are perceived or believed to offer relative benefits advantages over more traditional face-to-face encounters..$^{40,42}$

- Compatibility is the degree to which an innovation is perceived with the need and existing values of potential adopters. The adoption rate is suggested to increase when the innovation is compatible with the adopter's needs, socio-cultural values and beliefs and previously introduced ideas. ${ }^{41}$

- Trialability is the degree to which an innovation may be experimented with on a limited basis; it is important, since in case the innovation is easy to use for the first time without substantial consequences, the customer has the possibility to gather information about the innovation and attach a meaning to it, which in turn reduces the uncertainty associated with the innovation..$^{4}$

- Observability is the degree to which others can observe the result of innovation and an indication of the chance to see others use the SST. ${ }^{46}$ 
- Complexity is the degree of perceived difficulty in understanding and using the innovation. Any new idea may be classified on the complexity-simplicity continuum, but it is also a perceived attribute to potential adopters.$^{41}$ Moreover, two dimensions were suggested to analyze services: First, service complexity, defined as the number and intricacy of steps required to perform the service. Second, service divergence, which is the degree of freedom allowed in or inherent to a particular sequence of the process. ${ }^{47}$

- Perceived risk (PR) is the extent to which technology-enabled services are perceived to be sufficiently safe, secure and reliable to use.$^{40}(\mathrm{PR})$ is commonly thought of as feeling uncertainty regarding possible negative consequences of using a product or service, such as system failure and other risks associated with using the service. This is associated with a number of ideas such as, performance risk, financial risk, social risk, time risk, ${ }^{32,48}$ and psychological risk . ${ }^{49}$

- Perceived control: Locus of control is described as a belief individuals hold that failures or successes of the usage of SST are mainly resulted from their own actions or due to external uncontrollable factors. ${ }^{2}$ Previous studies posit that individuals' locus of control is related to motivation, beliefs, adoption, emotions, satisfaction, and behavioral intentions of innovative ideas. Moreover, it refers to a customer's sense of independency and of mastery over the processes and outcomes of the service interface. It is also a specific situation (psychological outcome) that is often influenced by environmental conditions and customer traits, such as self-efficacy in handling a specific technology $50,51,52,53$

- Trust: The infusion of technologies in service encounters may not be welcomed by customers, regardless of the obvious benefits. Furthermore, two main concerns to the adoption of SSTs by customers have been proposed: the preferences of some customers for interpersonal encounters during service, and the issue of privacy and confidentiality. ${ }^{54}$ Exchange theories posit that trust is a catalyst in customer marketer relationships because it provides expectations of competent, reliable performance and successful transactions. Trust includes three subdimensions: ability, benevolence, and integrity. High levels of customer trust in technology encourage satisfaction with SSTs and purchase intentions. ${ }^{9,32}$

- Perceived Ease and Perceived Usefulness: Perceived ease of use is defined as 'the degree to which a person believes that using a particular system would be free of effort ${ }^{55}$ In addition, ${ }^{43,56}$ concluded that ease of use is essential to customers' acceptance of the SST, and there is a link between technology discomfort and perceived ease of use. Self-service systems must be easy to use in order to achieve a higher adoption rate.57 on the other hand, usefulness is the subjective probability that using the technology would improve the way a user could complete a given task .38 Perceived usefulness is defined as 'the degree to which individual believe that using a particular system would enhance their job performance' . $^{32}$

- Reliability refers to the accurate functioning of an SST and the corresponding service, which positively impacts the attitude toward using SSTs ${ }^{58}$ If a service is unreliable, apologies and a friendly staff cannot compensate for it.$^{12}$

- Speed of Delivery: Expected speed of delivery is defined as the customer's expectation of the time it would take to actively perform the service. Customers today are highly sensitive to the speed of the service delivery; they usually overestimate the time taken to deliver a service. Some people prefer to perform the service themselves specifically to reduce delivery time.43,59. 60 found that time was very important to those who preferred self-service. Therefore, slow service delivery affects the overall perceptions of service quality.Thus, if customers expect that a service will be delivered speedily, they are likely to evaluate the service more highly ${ }^{43,61}$

- Enjoyment refers to being enjoyed when someone uses technology-based self-services options . (0,62 $^{\mathbf{2}}$

\section{Customer Related Factors:}

The second main approach influencing the adoption of SSTs focuses on customer traits which include demographics, customer psychographics, and personality traits.

\section{Demographics}

Age, gender, education and income are of the most demographic researched variables in relation to SSTs since they offer good base for traditional marketing segmentation. Demographics have been examined as direct antecedents of usage, since they are influencing beliefs and attitudes or personality traits.$^{32,63}$ In a study by ${ }^{64}$, customer's age was shown to have little influence on adoption of self-scanning. In contrast, a study specifically of the age variable by ${ }^{65}$ found that there are differences in the adoption of SSTs between the different age groups. He divided his sample into three age groups: 18-28; 29-48 and 49+. The study concluded that as the segmentation is getting older, a negative effect has been reflected on three 
variables: preferences for SST to human contact, confidence to use SSTs, and belief in the benefit from using technology. SST users are younger on average than non-users. ${ }^{65,66}$ Younger customers have a high chance for purchasing and using new customer electronic products.$^{67}$ Aging has a complex effect on cognitive abilities. Age is also associated with a decline in morphological and functional structures, which are key resources for perceptual skills, working memory, processing speed, and the encoding of information into episodic memory. Moreover, verbal and computing skills reach their optimal level between the ages of 30 and 50 years and decline very slowly after 50 years of age ${ }^{47}$ People differ in their sensitivity to time-related issues depending on their educational background. People who have more highly qualified jobs and education levels tend to display more quantitative time orientation. This has led them to attach more importance to the time gain that comes with using SSTs. Newness of SSTs in itself may have some utility for customers. Higher education has generally been found to be positively associated to a higher probability of using new technologies ${ }^{\mathbf{6 6}}$

The interaction between demographics (e.g. age, gender, education and income) and personality traits (e.g. technology anxiety, need for interaction and technology innovativeness) and their effect on intentions to use SSTs was researched by. ${ }^{63}$ Their findings show that customer demographics influenced SST usage intentions through the mediating effect of personality traits. For example, men exhibited a greater level of technology innovativeness and less technology anxiety; older people needed more personal contact, showed more technology anxiety and less technology innovativeness; while customers with higher income were less anxious about technology. ${ }^{63}$

- Technology Readiness (TR) has been suggested as a factor that fosters or hinders the acceptance or rejection of new technology . ${ }^{22}$ TR is defined as "people's propensity to embrace and use new technologies for accomplishing goals in home life and at work" . ${ }^{68}$ New technology can generate both positive and negative feelings ${ }^{32,8}$; feelings of enjoyment ${ }^{32}$ or anxiety ${ }^{56}$ which directly or indirectly affect customers' attitude, beliefs, and behavior toward technology. ${ }^{15,69}$ Furthermore, eight paradoxical emotions that customer has to cope with regarding new technology have been identified as follows: control/chaos, freedom/enslavement, new/obsolete, competence/incompetence, efficiency/inefficiency, fulfilling/creating needs, assimilation/isolation, and engaging/disengaging. ${ }^{70}$

Technology readiness is based on four dimensions, two factors being motivators of new another two being inhibitors as follows : $:^{71,72,73}$

technology use and

(1) Optimism: A positive view of technology (belief in increased control, flexibility, and efficiency in life due to technology).

(2) Innovativeness: A tendency to be the first using a new technology (a tendency to be a technology pioneer and thought leader).

(3) Insecurity: Distrusting of technology and skepticism about its ability to work properly.

(4) Discomfort: A perception of lack of control over technology and a feeling of being overwhelmed by it.

- Need for human interaction is defined as a desire to retain personal contact with others during a service encounter. Historically, service encounters have involved interpersonal interactions between customers and service providers. These interactions allow for the development of interpersonal relationships between a customer and service provider. However, using SSTs, by definition, eliminates this interpersonal interaction ${ }^{38}$ The use of technologyenabled services would be influenced by the extent to which personal contact is perceived as needed or preferred. On the one hand, some people prefer technology-enabled service provision precisely because it eliminates the need for personal contact (interaction with service personnel and other customers) in addition they find it enjoyable.$^{10,58}$ On the other hand, others prefer to deal or interact with people rather than machines, which are often thought to be impersonal and incapable of providing personalized service.$^{43,58}$ Therefore, it is reasonable that customers who desire personal interaction in the service encounter may be reluctant to adopt and use technologically facilitated means of service provision $.40,74$

- Previous experiences with technology-based products and services have been shown to consistently play a role regarding SST adoption. Past negative experiences with automated systems and technological products are reasons for not wanting to use self check-in options of airlines. The lack of computer experiences seems to inhibit customers to adopt self-service technology.$^{3}$ Also, past experiences influence SST attitudes and behavior in a more complex manner. . $^{17,75}$

\section{Strategies for the Success of SST Kiosks}

The key factors for the success of SST kiosks are ${ }^{14}$ as follows: 
The interface design: It is one of the important factors in the use of kiosks. A well-designed interface should be evaluated in terms of the functional features from the users' perspective. The functional features will determine the efficient and effective work to complete the information search or transaction on the kiosks. An interface design with a simple but useful layout helps customers stay focused on what they want. Interface design of the kiosks also should meet customers' needs and wants which change over time. Interface design matters greatly to customers, affecting their perceptions of technologies and service encounters ${ }^{44,51,76}$ Therefore, updating kiosks with an improved interface design is one of the important concerns to service providers.$^{12}$

Accessibility: Accessible kiosks are mainly determined by their location. A good location increases visibility and therefore, the number of users.

Employee Readiness: Successful kiosks are designed with many human factors in mind. Although kiosks are designed to off services created by customers, employee assistance is still an integral part for kiosk success. Well trained employees encourage customers to use kiosks and help customers whenever they have problems while using kiosks. In this way, more customers appreciate kiosks and the company can effectively prevent service failures caused by difficulties with the system.

Promotion: The company aggressively announces the availability of SST kiosks to their customers to encourage kiosk use. The kiosks are featured in their advertisements, catalogs, and throughout the stores ${ }^{12}$

Fulfillment: Fulfillment is referred to as one of the most expensive and critical operations, but also as one of the most integral parts in improving customer service in multi-channel shopping. Accurate and timely delivery with no failures can be a competitive advantage to a company.

Communication strategies: Companies also focus on educating the customers on how to use new technology, minimizing unpredictable aspects of the technology, and assuring the benefits related with using the technology.$^{22}$

Advantages and Challenges of SSTs

Self-service technology provides advantages for service providers and customers alike. The main benefits to service providers from successfully implementing SSTs are: operational cost reduction, increasing customer satisfaction and loyalty, ${ }^{32,40}$ reaching of new markets, allow staff to be relieved from routine duties, labor reduction, more consistent service delivery, expanded service delivery, and increased operational efficiency. ${ }^{44,77}$ From the customers' perspective, SSTs provide greater flexibility to choose service delivery method, greater control over service delivery, ease of use, enjoyment with SST interaction, faster response, communication in native language, avoidance of service personnel, more privacy, and added convenience. They also save money and time. ${ }^{78,79}$

However, ${ }^{23}$ have found key drivers of customer dissatisfaction with SSTs as follows:

- Technology failure: Contrary to "did its job", failure occurred when the technology did not work as intended. This failure is a malfunction of delivery when the customer is interacting with the technology. Examples for this failure are broken machines, websites down, inability to log on the system, and failing to use personal ID.

- Process failure: it is the Failure in the process after the customer technology interaction. For example, an on-line banking customer might pay his/her bill on-line, however, process failure results in the customer not being credited with payment. This process failure causes substantial dissatisfaction since customers do not know about the failures until notified that they have not done something which they have actually done.

- Poor design: "Technology Design Problem" and "Service Design Problem" are two components of "Poor Design". Although the SST may function as designed, it performs in such a way that customers are dissatisfied with the service encounter; for example, an SST that is difficult to use or understand.

- Customer-driven failure: Some customers accept that the failure sometimes occurs because of their own actions. For example, ATM users may realize that entering the password incorrectly might have contributed to dissatisfaction with the service encounter.

- Cultural factors: Cultural constructs greatly impact a customers' attitude towards utilizing SST ${ }^{80}$ Culture is strong evidence that shared beliefs, expectations, values, attitudes and behaviors influence the use of communication and information technology. Culture beliefs are likely to have a significant effect on the use and acceptance of selfservice technology.$^{22,81}$

- The customer messes up: For example, the customers might lose their pin number or password, or fail to provide requested information ${ }^{80}$ 
- Lack of human interactions and elimination of social experience: Even people who have favorable attitudes toward technology may avoid SSTs because they cannot replace the personal interaction.$^{14,81}$

- Uncomfortable feelings toward technology (Technology discomfort): It is the tendency of an individual to feel uneasy, apprehensive, stressed or to have anxious feelings about the use of SSTs.$^{56}$

Moreover, the limitations of SSTs from a service provider perspective are related to investment expenses, and staff and customer training. Furthermore, companies struggle to persuade their customers to adopt new self-service technologies. If the service technology does not gain adoption with customers, the company may face increased expenses because it needs to keep the operational staff, as well as pay for the new technology. SSTs also reduce the points of customer contact during the service delivery process which leaves fewer chances for early detection of complaints and opportunities for service recovery. ${ }^{15,32}$

\section{Self-Service at the Airports}

In recent years the airlines have started using innovative check-in technologies. Self-service check-in kiosks are now an integral part of the airport facility. This process enables airlines to reduce the time and number of staff required, thus, saving substantial costs in operation. In addition, it reduces queuing time, increases productivity and enhances operational efficiency.$^{\mathbf{2 5 , 8 2}}$ The customer has a range of options to commence the check-in process. First, the passenger can scan his frequent flyer card, his passport or credit card in order to open his passenger file. Then, the kiosks will complete the checkin process, issuing a boarding card. The airlines vary with their respective kiosks' functional ability to issue baggage tags ${ }^{\mathbf{8 2}}$ Airlines have invested heavily in airport kiosks to allow customers to manage their reservations. Airport kiosks with touch screen displays, magnetic stripe card readers, and bar code scanners are now common in airports around the world. These kiosks allow customers to check-in for their flights, change or upgrade their seats, modify their reservation, and even purchase a ticket. Moreover, travelers without baggage can check-in and then proceed directly to the gate; and travelers with baggage can check in and then take their luggage to the baggage drop.$^{29}$

As the airline industry continues to grow and the demand for SST changes, airlines have taken hold of SST and have been able to provide customers with the technology they have longed to use. Airlines are now putting the power in the customers' hands and allow them to perform multiple tasks that once could only be completed by a service employee.$^{83}$ Furthermore, SST provides customers with various benefits that would not be possible if the customer used a service employee. These benefits include: increased control over the service delivery; as the customer is in control of the process, convenience; as SST is available at almost every hour and at multiple locations, reduction in customer wait times; as lines tend to be shorter, and flexibility in use; as many tasks can be completed in a central location for multiple airlines ${ }^{84}$

Airport SST consists of many sub-systems that help passengers take the necessary action by themselves. The systems currently adopted in many airports according to ${ }^{85}$ include:

- Information kiosk, which is a standalone terminal that provides information, goods and services ${ }^{86}$

- Ticketing kiosk, which is a place where passengers can review prices, purchase airline tickets, confirm reservations, check baggage and monitor flight times and status.. A self-service kiosk is able to confirm a traveler's identity by prompting him or her to input a confirmation number and insert the credit card used to purchase tickets. $^{33}$

- Common Use Self Service (CUSS) kiosk, which is a shared terminal with multiple airlines that helps ease congestion and reduce long lines at check-in counters.

- Retail kiosk, where customers can purchase food, magazines, or souvenirs and goods before or after a flight . ${ }^{14}$

International Air Transport Association (IATA) has announced a five-pronged strategy constituting the 'Simplifying the Business' initiative. This initiative launched in the year 2004, and it includes: ${ }^{19,87}$

- $\quad$ BCBP - Bar Coded Boarding Pass - assigned for electronic boarding passes.

- $\quad$ IATA e-freight - managing cargo freight through electronic messages, reducing paper work.

- CUSS - Common Use of Self-Service -Self service kiosks provided for easy passenger check-in without help of ground staff.

- $\quad$ BIP - Baggage Improvement Program - aimed at hassle free baggage transportation.

- $\quad$ Fast Travel Program - travel made easier by providing more self-service options for passengers. 


\section{Cairo International Airport and Common Use Self-Service (CUSS) Kiosks}

Common Use Self-Service (CUSS) is a shared kiosk offering check-in facilities to passengers without the need for ground staff. The CUSS can be used by several participating airlines in a single terminal ${ }^{\mathbf{8}}{ }^{\mathbf{T}}$ This evolving pattern enables passengers to obtain boarding passes, check baggage, and conduct other transactions at times and places of their convenience. Passenger check in procedures will gradually shift from check-in procedures performed at check-in counters to check-in procedures performed through self-service check-in facilities at the airport, such as CUSS. The trend is toward common use equipment which may consist of free standing column type or counter type workstations with built-in Automated Ticket and boarding pass printer. The CUSS is used by self-service passengers to check-in, seat allocation, boarding pass printing and baggage check-in in a common use environment ${ }^{25}$ Figure.2 represents A CUSS Kiosk Machine.

The CUSS concept is a kiosk platform to be shared by any number of CUSS standard conformed

check-in applications. It was developed by a mix of airlines, airports and suppliers.$^{30}$ Self-service check-in kiosks have become the common check-in mechanism and a permanent fixture in Europe, US and in many airport terminals. CUSS was designed to enable airlines to provide a range of passenger facilities at a shared kiosk. In 2003, CUSS kiosks began to be deployed across airports worldwide in significant numbers ${ }^{89,}{ }^{90}$ In the Middle East region, it started as a dedicated selfservice, and the first CUSS kiosk have been installed at Cairo International Airport terminal building 3 (TB3) by the airport's systems supplier - ARINC incorporated and Société Internationale de Télécommunications Aéronautiques (SITA), the world's leading service provider of integrated IT business solutions and communication services for the air transport industry. ${ }^{25,91}$ Figure. 3 shows the penetration of CUSS across airports worldwide.

In 2006, ARINC Managed Services was contracted to provide advanced passenger check-in systems and IT technologies for TB3 at Cairo International Airport. These IT systems included: Common Use Terminal Equipment (CUTE), Common Use Self-Service (CUSS), IMUSE Common-Use Passenger Check-In and Departure System, IP-enabled AirVUE Flight Information Display System (FIDS), AirDB Airport Operational Database (AODB), Local Departure Control System (LDCS), Biometric Systems (BS), Ramp Management System, Local Area Network ( LAN), Information Kiosk System, Airport Recourse Management System, Network Management System, Voice over IP (VoIP), Information Broker System (IBS), and Baggage Reconciliation System (BRS).$^{91,92,93}$

The kiosk systems currently employed at most primary airports can be divided into two groups: CUSS kiosks, which comply with the IATA CUSS specifications and are shared by a number of airlines, and dedicated kiosks installed by individual airlines . ${ }^{19,82}$

The creation of the CUSS was to provide efficiency and profitability for all subscribing airlines. From the financial perspective the CUSS offers subscribing airlines a reduction in cost per passenger, reduced check-in processing time, physical infrastructure (reduction in queuing space and counter space) and length of time of kiosk return on investment. The CUSS kiosk has become convenient and desirable for both the airlines and passengers that utilize such devices, as its use can be beneficial to all. ${ }^{82,94}$ Furthermore, the main aspects to be considered in the placement of kiosks are ${ }^{18}$ :

- Visibility.

- Accessibility and movement of passenger traffic.

- Comfort and privacy of the passenger. 


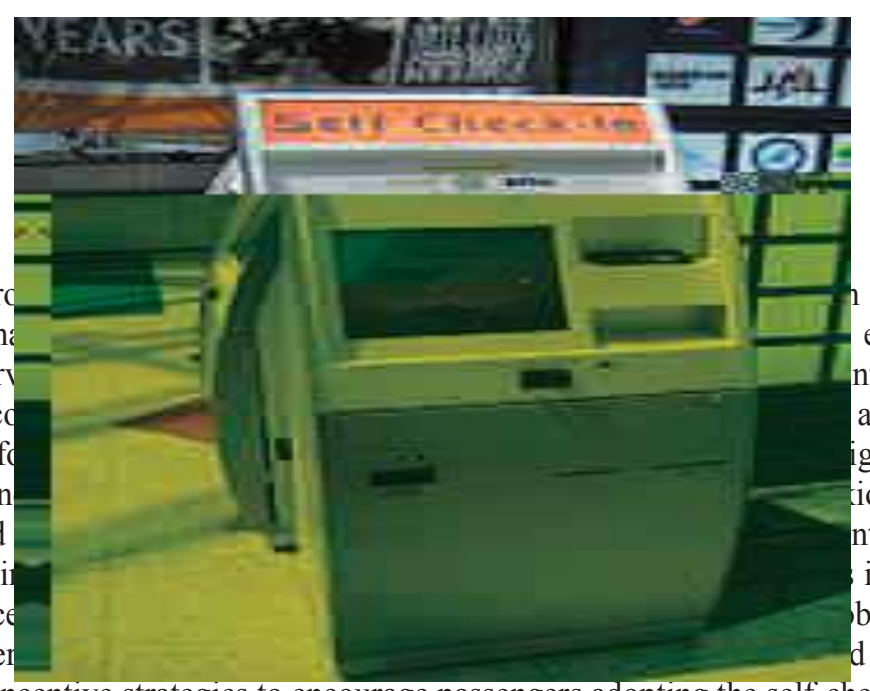

Figure (2): CUSS Kiosk Machine

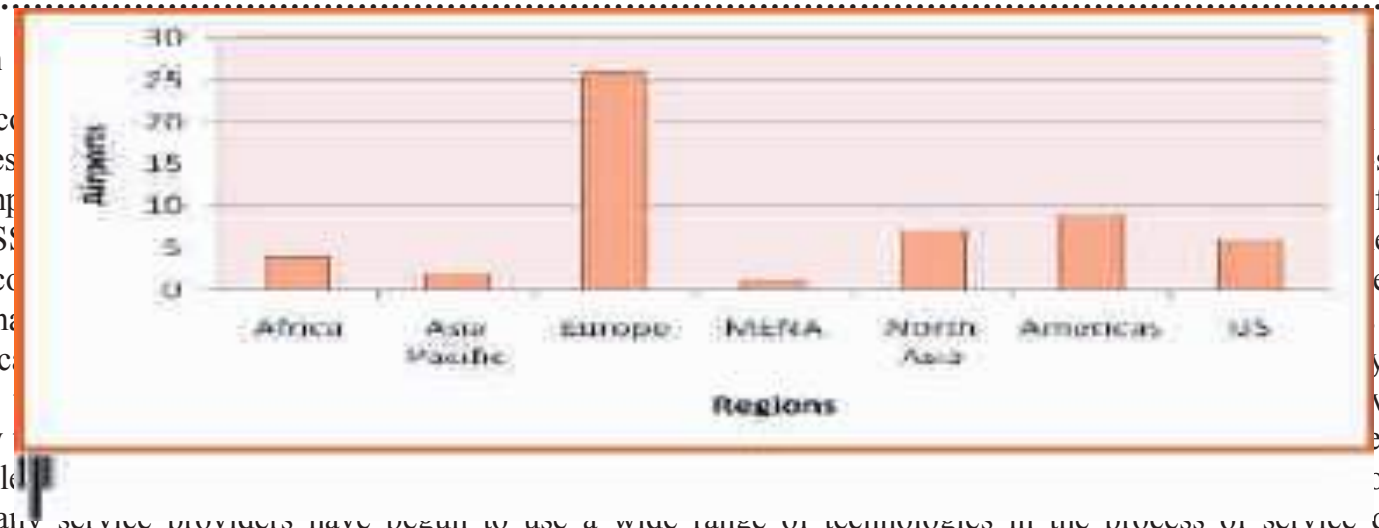

Figure (3): Penetration of CUSS at airports, Source: 18

\section{Methodology}

The study seeks to investigate passengers' intention toward using SST for airline check-in kiosks, and explore the obstacles to use self-service check-in kiosks at Cairo International Airport. A qualitative method has been adopted using in-depth interviews with open-ended questions, since in certain studies it is necessary to acquire the opinion of experts, particularly in qualitative and exploratory studies. Therefore, the researcher has interviewed a sample of 20 Executive directors of Cairo International Airport, check-in counter agents, managers of Egypt Air, and 30 passengers at Cairo International Airport. The interviews have included questions investigating the worth and benefits of using self-service check-in kiosks to airlines, airports and passengers, the limitations of self-service check-in technology for passengers, and the main reasons for the negative attitudes of passengers toward self-service check-in technology. These interviews also aimed at finding out what makes passengers resistant to use self-service check-in technology, and how airlines can encourage passengers to use the CUSS kiosks. The interview forms consist of three sections; the first section is designed generally to investigate the benefits of adopting self-service check-in technology to airlines, airports and passengers . The second section is developed to identify the main reasons for the negative attitudes of passengers toward self-service check-in technology and investigate obstacles of CUSS kiosk system perceived by passengers. The third section is developed to explore the role of airline companies to encourage passengers to use CUSS kiosks. 


\section{Findings}

It was observed that Cairo International Airport (TB3) has installed 10 CUSS kiosks; and despite long queues for various flights at the counter, none were using the kiosks. Passengers had rejected the kiosks and had some obstacles to use kiosks. They prefer to wait in the long queue following the traditional check-in methods instead of using self-service check-in machines. So, The in-depth interviews reveal a wealth of information on the passengers' intention to use technology-based self check-in services at Cairo International Airport from the passengers' and the airline managers' point of view in the following three section.

The first section: The benefits of adopting self-service check-in kiosks for airlines, airports, and passengers.

(1) As for airline managers and check-in counter agents, the majority of respondents (78\%) have demonstrated that the importance of the kiosk to the airlines is high. Obviously, it does not only reduce the manpower cost, minimize expenditures and increase the income of the company, but also assists in the promotion of the airlines' image by providing another checkin service option, an advanced one, to passengers. It also mitigates pressure at the check-in counters and reduces check-in processing time.

Relevantly, other respondents ( 9 employees) added that self-service check-in kiosks deliver fast and smooth services to airline passengers, and improve operational efficiency. Self-service check-in kiosks put control into the hands of the customer. In the airline industry, this control comes in the form of enabling the customer to select their own seat, request an upgrade, or change flights.

Moreover, many executive directors of Cairo International Airport ( 8 respondents) clarified that self check-in procedures appear more important and effective for business travelers who often carry one luggage only more than for other passengers.

(2) Regarding passengers: A number of passengers (67\%) have assured that self-service check-in kiosks act as a time saver for passengers as they allow passengers to cut down on time wasted standing in line. Furthermore, they provide customers with various benefits, such as flexibility in use, avoiding service personnel, increasing control over the service delivery, and convenience. They also act as a space saver for airports.

The second section: The main reasons for the negative attitudes of passengers toward self-service check-in kiosks, and obstacles to using CUSS Kiosk perceived by passengers.

(1) The results indicate that high percentage of passengers (82\%) argue that there are several impediments which prevent them to use such machines: Firstly, they hesitate to use self check-in machines for fear of making mistake, due to its complex interface; they do not know how to use it and they are afraid to take any risk by doing wrong interaction with selfservice check-in machines. Therefore, passengers still prefer interaction with front-line employees.

Furthermore, some respondents (4 passengers) also claimed that such kiosks have not been advertised or promoted, this most certainly precludes use; they have never seen that kind of machine and cannot recognize it. Furthermore, these kiosks are not visible due to its location at the airport.

Other respondents (5 passengers) added that passengers with luggage had to queue again for luggage services at the checkin counters for delivering the baggage. So, this process leads to waste of time as they do not get the bag-tag through self check-in kiosks.

Secondly, many respondents (17 passengers) pointed to issues concerning the obstacles related to CUSS Kiosk system. They stated that they have avoided using it due to Kiosk service failure and system breakdown, and the new procedures are not trusted completely for them.

(2) From the leaders/mangers at Cairo International Airport and check-in counter agents' viewpoint: The majority of respondents (84\%) pointed out that passengers are not commonly using Self-service check-in kiosks and had rejected it due to some obstacles, such as the lack of passengers' assistance to complete the process through the self-service check-in kiosks, and the airline staff's lack of training. Moreover, personal characteristic, beliefs, and attitudes of the passengers as well as cultural differences and level of education are also quite important factors that affect technology adoption.

Also, other station directors of Egypt air at Cairo International Airport have mentioned that a primary concern acting as impediments to the promotion of the kiosk service is the passengers' sense of insecurity and uncertainty when facing this innovative type of self check-in service. Moreover, passengers would worry about the consequences of using the kiosks. Simply, passengers are unwilling to shoulder the risk of possible inaccuracies when using the kiosks. In addition, they are not sure about the service quality of the kiosk, such as accuracy, and compatibility. Furthermore, if the passengers were not 
able to have self-efficacy in controlling the kiosks' operation processes, they would not tend to use them. Finally, passengers' inclinations for personal interaction might restrain the adoption of the kiosks.

The third section: The role of airline companies to encourage and promote passengers' use of CUSS kiosks.

(1) The majority of passengers ( $75 \%$ ) have agreed that they should be personally guided to use the kiosk by the employees; and airlines should try to change the passengers' attitude toward the kiosks in the future through extensive promotion. Suggested promotional strategies may include vigorous assistance by frontline employees, enhancement of the kiosks' stability, efficiency, accuracy and simplicity of use, and reduction of the adoption risk perception. Moreover, airlines have to establish marketing strategies to encourage passengers to use the cost-effective check-in services.

(2) A high percentage of airline managers and check-in counter agents (86\%) have ensured that it is very important to encourage passengers to use CUSS kiosks through different methods; airlines can give passengers some rewards such as special offers or promotion (e.g. free miles or ticket price discounts for their next flight).

Other executive directors of Cairo International Airport have suggested that airlines and airports' authorities should understand the factors affecting passengers' attitudes and realize the passengers' demands for this new check-in service before being introduced or extensively used. Airlines have to focus on educating customers on how to use check-in kiosks, for example, by organizing campaigns where employees show customers how to use the kiosks.

\section{Conclusion}

Airlines are eager to streamline their organization and apply new information technology to face the challenges of a competitive global market. However, the implementation of new technology is time consuming and requires human resources and enormous capital investment. Furthermore, the implementation of new technology involves innovation in organizational operation and even changes in its competitive mode. Although the widespread application of airport selfcheck-in services has benefited passengers, airlines and airports, passengers do not possess entirely positive attitudes toward it. However, the new procedures (self-service check-in kiosk) are not trusted completely. So, operated check-in procedures are still needed. Thus, exploring the potential obstacles to applying kiosks at check-in services is an issue of critical concern to the aviation industry. Also, low kiosk use and negative response to self-service check-in kiosks are directly related to systemic issues which impede kiosk use. Kiosk-service failures are clearly related to the lack of consistent service personnel to inform and assist passengers to use this service. Therefore, airlines should encourage those passengers who have not yet used kiosks to increase the overall kiosk usage. Finally, airlines should study and review the impact SST has on airlines and customers prior to selecting specific technologies to put in use, and they should also train their employees to know how to use the SST which then results in improved customer use.

\section{References}

(1)Lin, J.C. and Hsieh, P .(2011), Assessing the Self-service Technology Encounters: Development and Validation of SSTQUAL Scale. Journal of Retailing ,87 (2), 194-206.

(2)Oyedele, A. and Simpson, P(2007). An empirical investigation of consumer control factors on intention to use selected self-service technologies. International Journal of Service Industry Management ,18(3), 287-306.

(3)Jasmand, C.(2006) The Adoption of Self- Service Technologies : The Role of Consumer Readiness, Trust, and Experiences , Master Thesis, University of Maastricht. Available at: http://www.grin.com/en/e-book/75028/theadoption-of-self-service, Access on 07/12/2012.

(4)Frary, M. (2005) Self-service future or fad? Amadeus, available at : http:// www.amadeus.com/benelux/documents/corporations/Self-service_white · ...PDF[ access on 23/05/2012]

(5)Oh, H. ; Jeong, M. and Baloglu, S. (2011) Tourists' adoption of self-service technologies at resort hotels, Journal of Business Research, Article in press .

(6)Cunningham, L ; Young, C. and Gerlach , J ( 2008). Consumer Views of Self- Service Technologies .The Service Industries Journal, 28(6), 719- 732.

(7)Lee, J. and Allaway, A. (2002) Effects of personal control on adoption of self-service technology innovations . Journal of Services Marketing, 16(6), 553 - 572.

(8)Lin,J.C. and Hsieh,P. (2007) The influence of technology readiness on satisfaction and behavioral intentions toward selfservice technologies . Computers in Human Behavior, 23 , 1597-1615. 
(9)Liu, S.(2012)The impact of forced use on customer adoption of self-service technologies. Computers in Human Behavior, 28 , 1194-1201.

(10)Curran, J. ; Meuter , M. and Surprenant, C.(2003) Intentions to Use Self-Service Technologies: A Confluence of Multiple Attitudes. Journal of Service Research, 5(3), 209-224.

(11)Alcock, T. and Millard, N. (2007) Self-service — but is it good to talk? BT Technology Journal, 25 (3 \& 4 ) July/October , 313-320.

(12)Hsieh, C.(2005) Implementing Self-Service Technology To Gain Competitive Advantages, Communications of the IIMA , 5 (1), 77- 83 . Available at:http/www.iima.org/CIIMA/CIIMA\%205.1\%2077\%20Hsieh-9.pdf[accessed on 18 March 2012].

(13)Deng, L. (2012) Discrete Emotions and Trust in Self-Service Technology, Proceedings of the Southern Association for Information Systems Conference, Atlanta, GA, USA March 23rd-24th, 2012.

(14)Cho, H. and Fiorito, S.(2010) . Self-Service Technology in Retailing. The Case of Retail Kiosks, Symphonya . Emerging Issues in Management, n. 1, pp. 42-54. Available at: http// webdepot.gsi.unimib.it/symphonya/RePec/pdf/symjournl05.pdf[accessed on 02April 2012].

(15)Liljander,V.; Gillberg,F.; Gummerus, J.and van Riel,A. (2006) Technology readiness and the evaluation and adoption of self-service technologies. Journal of Retailing and Consumer Services, 13, 177-191.

(16)Wang, C.; Harris, J. and Patterson, P. (2009) Situational Influences in the Choice of Self-Service in a Multi-Channel Retail Context , ANZMAC, Available at: http://www.duplication.net.au/ANZMAC/09papers/ANZMAC2009.261-pdf , [Access on 20 May 2012 ]

(17)Wang, C.; Harris, J. and Patterson, P.(2012) Customer choice of self-service technology: the roles of situational influences and past experience. Journal of Service Management, 23 (1), 54 - 78.

(18) Baxi, M. (2007) Developing A Model To Analyze Impacts Of Self- Service And Web Check-In at Airports , the degree of Master of Science in Airport Planning and Management, Cranfield University.

(19)Chang, H.L. and Yang ,C.H. (2008) Do airline self-service check-in kiosks meet the needs of passengers?. Tourism Management, $29,980-993$.

(20)Howes, J. (2006) Moving to Common Use Self-Service (CUSS), available at : http:// www. iata. org/whatwedo/stb/Documents/On\%20the\%20cusp\%20of\%20CU [ access on 24/10/2012].

(21)Wittmer, A.(2011) Acceptance of self-service check-in at Zurich airport. Research in Transportation Business \& Management, 1 (1), 136-143.

(22)Kusumasondjaja, S.(2009) . Consumer Characteristics and Responses to Failures of Self-Service Technology, Available at: http// www.duplication.net.au/ANZMAC09/papers/ANZMAC2009-248.pdf[accessed on 02April 2012].

(23)Srijumpa , R. and Speece, M. (2004) Understanding Technology-Based Self-Service Encounters: Asian Services In The New Era, Asia Academy OF Management Fourth Conference "Moving Forward: Leading Asia in a New Era" Shanghai, China December 16-18, 2004.

(24)Grenci, R. and Watts, C.( 2007) Maximizing customer value via mass customized e-consumer services, Business Horizons , 50, 123-132.

(25)Abdel Aziz,S .; Hegazy, A. and Elabbassy, A. (2010). Study of Airport Self-service Technology within Experimental Research of Check-in Techniques Case Study and Concept. International Journal of Computer Science Issues, 7 (3) No 1, 17-26.

(26)Nysveen, H. and Pedersen, P. (2011) . Best practices and empirical analysis for the improvement of customer experience, SNF Working Paper No 05/11.

(27)Bitner, M. (2007) Self-Service Technologies: Innovation and Execution, IEEE/INFORMS NSF Workshop on Service Science, Available at: http//www.personal.psu.edu/gxq102/Research/NSFWorkshop2007/2007NSF/NSF...28/03/2012 06.00 pm[accessed on 28 March 2012]. 
(28)Bitner, M.; Ostrom , A. and Meuter, M. (2002) Implementing Successful Self-Service Technologies. The Academy of Management Executive, 16(4), 96-108.

(29)Castro,D. ; Atkinson, R and Ezell, S(2010) Embracing the Self-Service Economy, The Information Technology \& Innovation Foundation, Available at: http// www.itif.org/publications/embracing-self-service-economy [accessed on 28 March 2012].

(30)Neo, K C. (2010) Embracing self-service technology for hotel productivity growth, University of Nevada, Las Vegas UNLV Theses, Master of Hospitality Administration http://www.digitalcommons.library.unlv.edu/hgs_Profpapers/index.2.html.

(31)Phongkusolchit ,K.( 2008) Improving Self-Service Technologies Utilization: The Potential Impacts OF Technology Anxiety, Need For Interaction With Service Employees, And Expected Service Quality, Southern Illinois University Carbondale, Department of Management, Doctor of Philosophy Degree.

(32)Kelly,P.; Lawlor, J and Mulvey,M(2010). A Review of Key Factors Affecting Consumer's Adoption And Usage of Self- Service Technologies In Tourism, Available at: http//www.shannoncollege.com/wpcontent/uploads/2009/12/THRIC-2010-Full... /... [accessed on 13 March 2012].

(33)Kasavana, M .(2010). Emergent Service Delivery Technologies. The Journal of International Management Studies, $5(2), 159-167$.

(34)Meuter, M.; Ostrom, A.; Roundtree, R. and Bitner, M.(2000). Self-Service Technologies:

Understanding Customer Satisfaction with Technology-Based Service Encounters, Journal of Marketing , 64, 50-64.

(35)Yang, M. and Park,K.H.(2010) Self-Service Technologies (SSTs): determinants of adoption and its post-usage outcomes from a focal company perspective, Int. J. Services and Operations Management, Available at: http://www.markyang76.files.wordpress.com/2010/10/ijsom-8303-yang-and-park.pdf ,[accessed on 23 May 2012]

(36)Preda, O. ;Ivănescu, I. and Furdui, I. ( 2009) Self- Service Technologies Speak For Themselves, Romanian Economic and Business Review , Romanian-American University, 4 (1), 11- 17.

(37)Bashir ,M. and Albarbarawi,S.( 2011) Factors Influencing the Adoption of Self Service Technologies (SSTs) : A study of attitudes towards SSTs (Internet Banking, Online Shopping and Self-Check-In Machine at the Airports) and the influence of new technologies (smart phones and tablet computers), Master 's Thesis, Umeå Universitet, Institutionen för Informatik, Available at: http:// www.essays.se/about/Technology-Based+Self-Service,[accessed on 19November 2012]

(38)Curran, J. and Meuter, M. (2005).Self-service technology adoption: comparing three technologies. Journal of Services Marketing, 19 (2), 103-113.

(39)Kim, J. ; Christodoulidou, N. and Brewer, P. ( 2012) Impact of Individual Differences and Consumers' Readiness on Likelihood of Using Self-Service Technologies at Hospitality Settings, Journal of Hospitality \& Tourism Research, 36( 1), 85-114.

(40)Walker, R and Johnson, L (2006) Why consumers use and do not use technology-enabled services. Journal of Services Marketing, 20(2) , 125-135.

(41)Habibi, S.(2008) Intention to Adopt Technology -Based Self- Services, The case of Airport Self Check- in Service for Iran Aviation Industry, Master 's Thesis, Lulea University of Technology, Available at: http://www epubl.ltu.se/16530187/053/2008/LTU-PB-EX-08053-SE.pdf · PDF, ,[accessed on 02 April 2012] .

(42)Wang, J. and Namen, J. (2004) Customer Adoption of Technology -Based Self- Services, A Case Study on Airport Self Check- in Service, Master 's Thesis, Lulea University of Technology

Available at: http://www._epubl.ltu.se/1404-5508/2004/085/LTU-SHU-EX-04085-SE.pdf · PDF ,[accessed on 30April 2012]

(43)Dabholkar, P. (1996) Consumer evaluations of new technology -based self service options: An investigation of alternative models of service quality, International Journal of Research in Marketing, 13(1), 29-51.

(44)Hilton, T. and Hughes, T. (2008). Co-production and co-creation using self service technology: The application of service-dominant logic, Otago Forum 2, Academic Papers, Paper no: 4, pp.22-40, Available at: http//marketing.otago.ac.nz/events/OtagoForum/Final\%20forum\%20papers/... [accessed on 18 March 2012]. 
(45)Walker, R. ; Lees, M.C.; Hecker, R. and Francis, H. (2002) "Technology-enabled service delivery: An investigation of reasons affecting customer adoption and rejection". International Journal of Service Industry Management, Vol. 13( 1) , 91 - 106.

(46)Fui , C.K.(2008) Self-Service Technology And Internet Banking: An Investigation Of Consumers’ Trial Decision , Faculty Of Business And Accountancy, University Of Malaya, Master of Business Administration.

(47)Simon, F. and Usunier, J.C. (2007). Cognitive, demographic, and situational determinants of service customer preference for personnel-in-contact over self-service technology. International Journal of Research in Marketing , 24 , 163-173.

(48)Natarajan,T. (2010) Customer's Choice amongst Self Service Technology (SST) Channels in Retail Banking: A Study Using Analytical Hierarchy Process (AHP) . Journal of Internet Banking and Commerce, 15(2) .

(49)Featherman, M. and Pavlou, P.( 2002) Predicting E-Services Adoption : A Perceived Risk Facets Perspective, Eighth Americas Conference on Information Systems, 1035-1046 .

(50)Lema, J. (2009) Preparing Hospitality Organizations for Self-Service Technology. Journal of Human Resources in Hospitality \& Tourism,8(2), 153-169.

(51)Zhu , Z. ; Nakata, C ; Sivakumar,K. and Grewal,D.( 2007), Self-service technology effectiveness: the role of design features and individual trait. Journal of the Academy of Marketing Science, 35,492-506.

(52)Zhu, Z. (2002) Fix it or leave it: Antecedents and consequences of perceived control in technology-based self-service failure encounters, the degree of Doctor of Philosophy in Business Administration ,University of Illinois , Chicago .

(53)Oh, H. and Jeong, M.(2009). A Self-Service Technology Adoption Model in the Resort Hotel Environment, Hospitality $\&$ Tourism Management International CHRIE Conference-Refereed

Track ,Available at: http// content.sp.npu.edu.tw/teacher/benson/Shared\%20Documents... [accessed on 14 March 2012].

(54)Bitner, M., Brown, S. and Meuter, M.(2000) Technology Infusion in Service Encounters. Journal of the Academy of Marketing Science, 28(1),138-149.

(55)Hsun Ho,S. and Yin Ko,Y. (2008) Effects of self-service technology on customer value and customer readiness: The case of Internet banking. Internet Research, 18(4), 427 - 446.

(56)Rose, J. and Fogarty, G.(2006). Determinants Of Perceived Usefulness And Perceived Ease Of Use In The Technology Acceptance Model: Senior Consumers' Adoption Of Self-Service Banking Technologies, Academy of World Business, Marketing \& Management Development Conference Proceedings, 2 (10), 122-129.

(57)Travica, B . (2008) Influence of Information Culture on Adoption of a Self-Service System, Journal of Information, Information Technology, and Organizations , Volume 3. Available at: http://www.questia.com/library/p409628/journal-of-information-information-technology,[accessed on 2012] .

(58)Dabholkar, P. and Bagozzi, R.P. (2002). An attitudinal model of technology-based self-service:moderating effects of consumer traits and situational factors. Journal of the Academy of Marketing Science, 30(3), 184-201.

(59)Fitzsimmons, J. (2003) Is self-service the future of services?. Managing Service Quality, 13

(6), $443-444$.

(60)Davis, D. ; Bagozzi, R.P. and Warshaw, P.R. (1989) User Acceptance of Computer Technology: A Comparison of Two Theoretical Models, Management Science 35 (8), 982-1003.

(61)Collier, J.E.(2006) Examining customers' intentions to use self-service technology through utilitarian and hedonic value judgments, the degree of Doctor of Philosophy in Business Administration ,University of Memphis, Chicago .

(62)Cho , S.(2011) Self-Service Technology : AN Investigation OF The Potential For Adoption In Apparel Retail Settings, the degree of Doctor of Philosophy ,University of North Carolina at Greensboro.

(63)Lee, H.J.; Cho, H.J.; Xu ,W. and Fairhurst , A.(2010). The influence of consumer traits and demographics on intention to use retail self-service checkouts . Marketing Intelligence Planning , 28 (1), 46-58.

(64)Dabholkar, P., Bobbitt, L. and Lee, E.(2003) Understanding Consumer Motivation and Behavior Related to SelfScanning in Retailing: Implications for strategy and research on technology-based self-service. International Journal of Service Industry Management, 14(1), 59-95. 
(65)Dean, D.(2008) Shopper Age and the Use of Self-Service Technologies, Managing Service Quality, 18(3), 225-238.

(66)Meuter, M.; Bitner, M.; Ostrom, A. and Brown, S.(2005) Choosing Among Alternative Service

Delivery Modes: An Investigation of Customer Trial of Self-Service Technologies . Journal of Marketing, 69 , 61-83.

(67)Weijters, B. ; Schillewaert, N. ; Rangarajan, D. and Faik, T. (2005) Customers' usage of Self Service Technology in a Retail Setting, Vlerick Leuven Gent Management School ,Working paper series ,available at : http:// www ideas.repec.org/p/vlg/vlgwps/2005-19.html[access on 28/03/2012].

(68)Parasuraman, A .(2000). Technology readiness index (tri): a multiple-Item scale to measure readiness to embrace new technologies. Journal of Service Research 2 (4), 307-320.

(69)Meuter, M.; Ostrom, A.; Bitner, M. and Roundtree, R.(2003) The influence of technology anxiety on consumer use and experiences with self-service technologies. Journal of Business Research, 56 (11) , 899- 906 .

(70)Mick, D. G., \& Fournier, S. (1998). Paradoxes of technology: consumer cognizance, emotions, and coping strategies. Journal of Consumer Research, 25(2), 123-144.

(71)Chen,S.C. and Han Li,S.(2010) Consumer adoption of e-service: Integrating technology readiness with the theory of planned behavior, African Journal of Business Management, 4(16), 3556-3563.

(72)Lin,J.C. and Hsieh, P.(2006).The role of technology readiness in customers' perception and adoption of self-service technologies . International Journal of Service Industry Management, 17(5), 497-517.

(73)Stockdale ,R.(2007). Managing customer relationships in the self-service environment of e-tourism . Journal of Vacation Marketing, 13( 3), 205-219.

(74)Gelderman,C.J.; Ghijsen,P.W.Th ; Diemen,R.V.(2011) Choosing self-service technologies or

interpersonal services- The impact of situational factors and technology- related attitudes,

Journal of Retailing and Consumer Services, Volume 18 , Issue 5 , PP. 414- 421.

(75)Lu, J.L. ; Choi,J.K. and Tseng,W.C.(2011) Determinants of passengers' choice of airline check-in services: A case study of American, Australian, Korean, and Taiwanese passengers .

Journal of Air Transport Management, 17 (4), 249-252.

(76)Robertson, N. and Shaw, R.(2008) Exploring self-service technology powerlessness, in ANZMAC 2008 :

Australian and New Zealand Marketing Academy Conference 2008 : Marketing : shifting the focus from mainstream to offbeat, Promaco Conventions, Canning Bridge, W.A., pp. 1-7.

(77)Dickinson, C. (2006). Self-service Technologies: The Affect on Hospitality Branding, available at:http//www.hospitalityupgrade.com/_magazine/magazine_Detail-ID-42.asp[accessed on30April 2012].

(78)Kasavana, M. and Connolly, D.(2005) . Self- Service Kiosks : Hotels Expand Guest Services. The journal of Hospitality Financial And Technology professionals . Special Issue Self- Service Technology , 20( 2), 11-14 .

(79)Lin,J.C. and Chang, H.C.(2011) .The role of technology readiness in self-service technology acceptance . Managing Service Quality, 21(4) , 424-444.

(80)Coker,F. (2009) Consumer Attitudes And Behavioral Intention Towards Self-Service Kiosks In Hotels : A Cultural Perspective, the degree of Master of Science in Hospitality Information Management, University of Delaware.

(81)Fisher, G \& Beatson, A.T. (2002) The impact of culture on self-service on technology adoption in the hotel industry. International Journal of Hospitality and Tourism Administration, 3(3), 59-77.

(82)Black, C.(2009) Self-Service technologies: Chinese Passenger Responses to Airport Check-In, Master 's Thesis, National Cheng Kung University, Institute of International Business .

(83)Lu, J.L. ; Chou,H.Y and Ling,P. C. (2009) Investigating passengers' intentions to use technology-based self check-in services . Transportation Research Part E: Logistics and Transportation Review, 45 Issue (2) , 345-356. (84)Drennen, H. (2011) Self Service Technology in Airports And the Customer Experience, UNLV Theses, Master of Hospitality Administration, available at : http:// www.digitalscholarship.unlv.edu/thesesdissertations/1053[ access on 22/01/2013]. 
(85)Abdullah, N.Ab.H.(2012) Technology Readiness and Users Satisfaction towards Self-Service Technology at Malaysian Airport . Information Management and Business Review , 4( 8), 453-460.

(86)Moerloose, C. ; Antioco, M.; Lindgreen, A. and Palmer, R.(2005) Information kiosks: the case of the Belgian retail sector. International Journal of Retail \& Distribution Management, 33( 6) , 472-490.

(87)IATA (2011) The International Air Transport Association ,available at : http://www. internationalairtransportassociation. com [ access on 24/10/2012].

(88)wikipedia (2011) Common Use Self Service available at: http://www. en.wikipedia.org/wiki/ Common_Use_Self_Service[ access on 24/10/2012].

(89)Airport Business (2012) The evolution of the kiosk ,available at : http://www.airport-business.com/2012/06/theevolution-of-the-kiosk [ access on 24/10/2012].

(90)Kidwell, H. (2007) Going it Alone: Self-Service Check-In Kiosks, Airport Technology, available at: http:// www. airport-technology. com/features/feature1179 [ access on 24/10/2012].

(91)Annapolis , M. (2009) ARINC Supports the Opening of Cairo Terminal 3 with 14 Advanced Airport Systems Installed and Running, available at: http:// www.arinc.com/news/2009/08-17-09-arinc-supports-opening-of-Cairo-terminal3.html[ access on 24/10/2012].

(92)Cairo International Airport (2012) available at: http:// www.airport-technology.com//projects/cairointernational [ access on 24/10/2012].

(93)Ministry of civil Aviation (2012) Egyptian Holding Company for Airports and Air Navigation, available at: http:// www:ec.europa.eu/.../modes/air/events/doc/eu_africa/session_6_cairo.pdf .

(94)Gualandi,N.; Mantecchini, L. ; Paganelli,F. ( 2011) The Impact Of New Technologies In Airport Passengers' Processes, available at : http:// wwwgeocities.ws/icts_papers/Papers/Gualandi,\%20Montecchini,\%20 ...PDF [ access on $22 / 01 / 2013]$.

\section{معوقات تطبيق تكنولوجيا الخدمة الذاتية في مطار القاهرة الدولي}

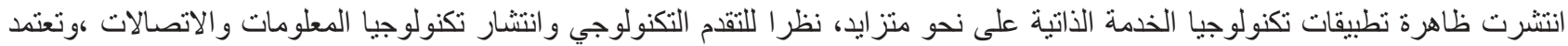

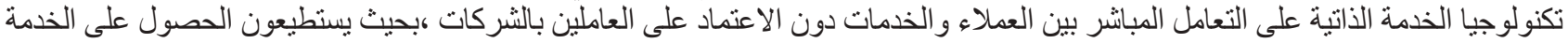

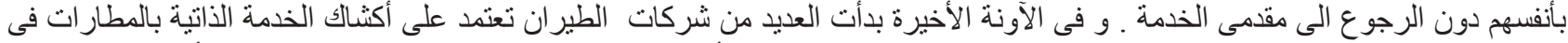

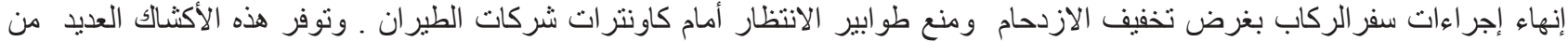

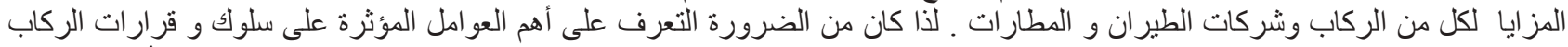

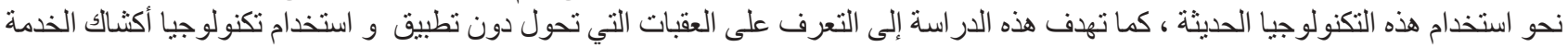

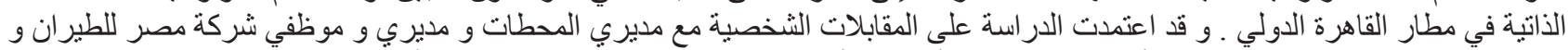

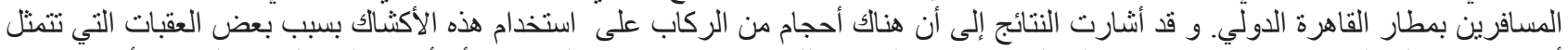

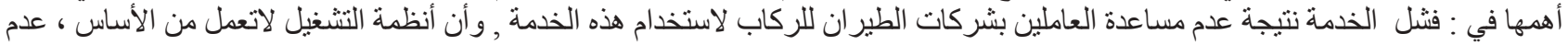

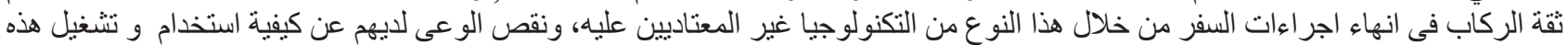

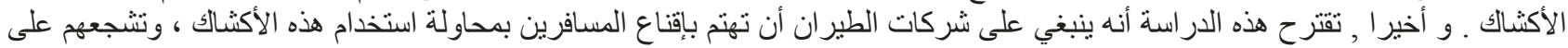

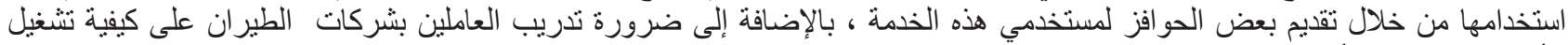

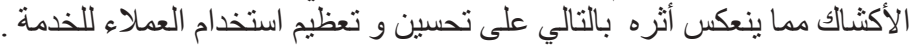




\title{
The Influence of Corporate Social Responsibility on Customer Loyalty:
}

\section{Evidence from the Travel Agencies and Hotels}

\author{
Mohamed Abou Taleb Mohamed \\ Hotel Studies Department
}

\author{
Toka Mahrous Fahmi \\ Tourism Studies Department
}

University of Sadat City

\begin{abstract}
Despite the increasing interest in corporate social responsibility (CSR) marketing practices, the role of CSR has little been explored in the area of tourism and hospitality marketing, especially in regard to the potential effects of CSR initiatives on customer responses. Also, there are few scholars, if any, who overviewed this concept in the developing countries. By understanding the effectiveness of CSR practices in the market place and its impact on customers' responses towards the company, travel agencies and hotel operation will be able to attract new customers as well as keep strong relationships with current customers. CSR marketing will provide the firm a competitive edge over its competitors. This paper explores how customers' perceptions of firms' corporate social responsibility (CSR) determine customers' behaviour and influence customer loyalty through satisfaction and commitment. To investigate such influence, data were collected through a questionnaire distributed to a sample of 350 customers of Egyptian hotels and 300 customers of Egyptian travel agencies. A total of 335 responses from hotels' customers and 260 responses of travel agencies' customers were collected and analyzed using structural equation modelling method. Results showed that CSR contribute to achieving customer loyalty in both sectors and confirmed the roles of satisfaction and commitment as mediating variables. These results imply that CSR can be used as a main tool for marketing strategy. Certain CSR marketing actions could work better than others to create positive identification and image of the company.
\end{abstract}

Keywords: Corporate Social Responsibility; Customer Behaviour; Satisfaction; Commitment; Loyalty.

\section{Introduction}

Corporate social responsibility (CSR) is the commitment of business to contribute to sustainable economic development, working with employees, their families, the local community and society at large to improve their quality of life (World Business Council on Sustainable Development, 2000). Although some studies noted that the beginning of the academic interest in CSR could ascend to the 1850s (Smith, 2003), it is only recently that it has acquired the position it currently has within teaching and research institutions, non-governmental organizations (NGOs), corporations, governments and agencies (Garriga and Mele, 2004).

Top companies in different industries responded to their stakeholders, consumers, societies and governments and launched various initiatives to reveal their CSR commitments. For example, General Electric initiated "Ecomagination" (a neologism combining ecology with imagination) as its strategic key word (Business Wire, 2005) and ever since has continued to disclose extensive reports on environmental issues. HSBC, a leader in global banking, declared a carbon neutral initiative, showing its commitment to CSR for climate change problems (BBC News, 2004), while in 2008, Wal-Mart launched its new jewellery line called "Love, Earth" in which Wal-Mart only uses gold, silver and diamonds from mines and manufacturers that meet sustainability standards established by Wal-Mart (Fibre2fashion, 2008).Parallel to this universal fashion of public and corporate attention to CSR issues, the hospitality industry and travel agencies have shown an ever increasing interest in CSR. For example, the number of CSR and environmental news items on a hospitality industry web site, Hospitality Net, increased from 63 in 1999 to 139 in 2007 with $10.4 \%$ compound annual growth rate while the number of overall news increased with just a $2.8 \%$ compound annual growth rate. More leading hospitality companies, including Hilton, Starwood, Choice Hotels, Starbucks and McDonald's, exclusively provide CSR related reports. Also, many travel agencies and airlines including British Airways, SAS Group, Cathay Pacific and Dragonair launched carbon-offsetting programs to help fund environmental projects (Armstrong, 2008; Kjelaggard, 2007).

Egypt has a powerful tradition of giving practiced in both the Christian and Islamic faiths. Christians offer "ushur" or tithes and Muslims offer "zakat" or alms giving. Charity and charitable institutions are rooted in the Egyptian society going back to the eleventh century. The most popular and primary institutional form of charity acknowledged at that time was the endowments known as "waqaf" which proliferated under the Mamluk period. The nineteenth century witnessed the birth of civil society and with the beginning of the twentieth century the number of powerful and active civil society institutions working for charity, social services, Islamic practices, women rights, education and advocacy increased. 